\title{
The genus Diplommatina Benson, 1849 (Gastropoda: Caenogastropoda: Diplommatinidae) in Nepal, with the description of seven new species
}

\author{
Prem B. BUDHA ${ }^{1, *}$, Fred NAGGS ${ }^{2} \&$ Thierry BACKELJAU ${ }^{3}$ \\ ${ }^{1,3}$ University of Antwerp, Evolutionary Ecology Group, \\ Universiteitsplein 1, B-2610, Antwerp, Belgium. \\ ${ }^{1}$ Central Department of Zoology, Tribhuvan University, Kirtipur, Kathmandu, Nepal. \\ ${ }^{2}$ Natural History Museum, Cromwell Road, London, SW7 5BD, UK. \\ ${ }^{3}$ Royal Belgian Institute of Natural Sciences, Vautierstraat 29, B-1000, Brussels, Belgium. \\ "Corresponding author: prembudha@yahoo.com \\ ${ }^{2}$ Email: f.naggs@nhm.ac.uk \\ ${ }^{3}$ Email: thierry.backeljau@naturalsciences.be

\footnotetext{
${ }^{1}$ urn:Isid:zoobank.org:author:666E50A6-920D-47C0-989B-D249F547DF39

${ }^{3}$ urn:Isid:zoobank.org:author:E6F42575-36AE-4AD7-98C6-D083EF052568
} \\ ${ }^{2}$ urn:lsid:zoobank.org:author:DF2B7468-4145-4F7D-A5A2-39E433C4AF6E
}

\begin{abstract}
This paper deals with the taxonomy and faunistics of the genus Diplommatina in Nepal. Altogether 16 species are reported, seven of which are new to science viz. D. abiesiana sp. nov., D. fistulata sp. nov., D. godawariensis sp. nov., D. maipokhariensis sp. nov., D. salgharica sp. nov., $D$. shivapuriensis $\mathrm{sp}$. nov. and $D$. syabrubesiensis $\mathrm{sp}$. nov. Information on nine previously reported species is provided: D. exserta Godwin-Austen, 1886, D. folliculus (L. Pfeiffer, 1846), D. miriensis GodwinAusten, 1917, D. munipurensis Godwin-Austen, 1892, D. oviformis Fulton, 1901, D. pachycheilus Benson, 1857, D. regularis Fulton, 1901, D. silvicola Godwin-Austen, 1886 and D. sperata W.T. Blanford, 1862. Although D. canarica was once reported from Nepal, it is not treated here as it is an endemic of the Western Ghats. A dichotomous identification key for all Nepalese species is presented.
\end{abstract}

Keywords. Diplommatinidae, Diplommatina, Nepal, identification key, taxonomy.

Budha P.B., Naggs F. \& Backeljau T. 2017. The genus Diplommatina Benson, 1849 (Gastropoda: Caenogastropoda: Diplommatinidae) in Nepal, with the description of seven new species. European Journal of Taxonomy 337: 1-30. https://doi.org/10.5852/ejt.2017.337

\section{Introduction}

Benson (1849) created the genus Diplommatina for Bulimus folliculus Pfeiffer, 1846. However, Benson (1849) erroneously placed Diplommatina folliculus in the family Carychiadae (= Carychiidae), because he overlooked the presence of an operculum in this species. Conversely, Gray (1850) did observe the operculum lodged inside the shell and therefore transferred Diplommatina to the Cyclophoridae. 
L. Pfeiffer (1856) erected the family Diplommatinidae (original spelling was Diplommatinacea) to accommodate the genus Diplommatina.

Diplommatina is a very speciose genus comprising several hundred species. Nevill (1878) listed 62 Diplommatina species in the Indian subcontinent and grouped them into six subgenera, viz. Diplommatina $(\mathrm{n}=43)$, Nicida Blanford, $1868(\mathrm{n}=8)$, Palaina Semper, $1865(\mathrm{n}=1)$, Arinia H. \& A. Adams, 1856 $(\mathrm{n}=1)$, Moussonia Semper, $1865(\mathrm{n}=2)$, Diancta Martens, $1864(\mathrm{n}=5)$ and Paxillus H. \& A. Adams, $1851(\mathrm{n}=2)$. All of these subgenera are now considered as full genera. Hanley $\&$ Theobald (1876) and Godwin-Austen $(1886,1897)$ figured most of the Diplommatina species of the Indian subcontinent known until then. Gude (1921) reviewed the Indian operculate land snails and summarised all previous literature on Diplommatina. He listed 82 species of Diplommatina for the Indian subcontinent and placed them into three subgenera, viz. Diplommatina $(\mathrm{n}=63$, including three subspecies), Metadiancta Möllendorff, 1898 ( $\mathrm{n}=11)$ and Sinica Möllendorff, $1885(\mathrm{n}=8)$.

South Asian diplommatinids are usually described on the basis of external shell characters. The density of radial ribs and features of the apertural and internal lamellar system are considered to be of critical value in recognising subgenera and species (Yamazaki et al. 2013; Liew et al. 2014; Neubert \& Bouchet 2015). Yet, the internal shell structures of diplommatinids are well characterized in only a few genera, such as Habeas Simone, 2013 (see Simone 2013), Diancta, Moussonia, Palaina (see Neubert \& Bouchet 2015) and Benigoma Kuroda, 1928 (see Hwang et al. 2009). Conversely, the internal lamellar system in Himalayan Diplommatina is largely unknown.

Hitherto, diplommatinids have been poorly studied in Nepal. Kuznetsov \& Schileyko (1997) reported four species of Diplommatina in Nepal, viz. D. canarica Beddome, 1875, D. oviformis Fulton, 1901, D. pachycheilus Benson, 1857 and D. sperata W.T. Blanford, 1862, whereas Budha et al. (2015) listed 10 species. The present paper is the first to provide descriptions of Nepalese Diplommatina, with illustrations of their internal lamellar system. As such, it deals with 16 species of Diplommatina currently reported from Nepal, seven of which are new to science. It does not treat $D$. canarica because this species is endemic to the Western Ghats. It also includes a dichotomous identification key for the Nepalese species. No attempt has been made to assign species to subgenera because the subgeneric classification of Diplommatina is in need of revision.

\section{Material and methods}

Specimens and shells were collected from 2006 to 2010 by hand searching and leaf litter sieving in the following areas in Nepal (Fig. 1): (1) Mahakali River corridor and its tributaries in far west Nepal, (2) the Kalingandaki River corridor in western Nepal, (3) Langtang and Shivapuri-Nagarjun National Parks, Phulchowki Hill in the Lalitpur District, Nagarjun Forest in the Kathmandu District and Siddha Cave area in the Tanahun District in central Nepal, and (4) Maipokhari in the Ilam District in eastern Nepal.

All species were identified by their shell characters. In addition to the shell sculpture, the shape of the peristome and the aperture as well as the internal lamellae are important characters to diagnose species. These characters can be easily studied by making shells transparent in gasoline (Vermeulen 1993). However, very fine spiral striations can be easily overlooked in old shells. Parietal lamellae can be observed only after removing the outer wall of the body whorls (i.e., breaking the shell) to expose their internal structure. The internal parietal lamellae of each species were studied by means of SEM images (Fig. 2B). To this end, shells were first cleaned with tap water and a fine camel-hair brush. The palatal lamellae are illustrated in separate drawings made with a stereo microscope. The shell structure terminology and the nomenclature of internal parietal and palatal lamellae used in this paper are given in Fig. 2 and are based on Neubert \& Bouchet (2015) (though slightly modified for the palatal lamellae). 
Shell height (SH) and shell width (SW) were measured on graph paper under a NIKON stereo microscope. Measurements are given in $\mathrm{mm}$, except for submillimetric measurements, which are approximate based on up and down scale from the midpoint between two lines at 0 and $1 \mathrm{~mm}$. However, for holotypes exact measurements were taken from SEM images.

Diagnoses are provided for all species from Nepal, except for D. pachycheilus, whose presence in Nepal is only known from a single, doubtful literature record (Kuznetsov \& Schileyko 1997). Type series and material from the collections in the London Natural History Museum, United Kingdom (NHM) and the Royal Belgian Institute of Natural Sciences, Brussels (RBINS) were studied, photographed and compared. All newly collected material is deposited in the Central Department Zoology Museum of Tribhuvan University (CDZMTU), Kathmandu, Nepal. Permanent mounts of the opercula were photographed with a digital camera attached to a stereo microscope and a PC at the Central Department of Zoology, Tribhuvan University, Kathmandu, Nepal. SEM images were taken at RBINS, Brussels.

\section{Character definitions}

- Columellaris (Fig. 2B): inner curved lamella along the columellar axis.

- Columellar tooth (Fig. 2A, 2C): a processus of the columellaris visible on the columellar lip in the aperture.

- Dorsal fold (Fig. 3C4, 8C4): fold or elevated part at dorsal part of the body whorl towards the aperture.

- Penultimate whorl (Fig. 2A): whorl above the body whorl towards the apex.

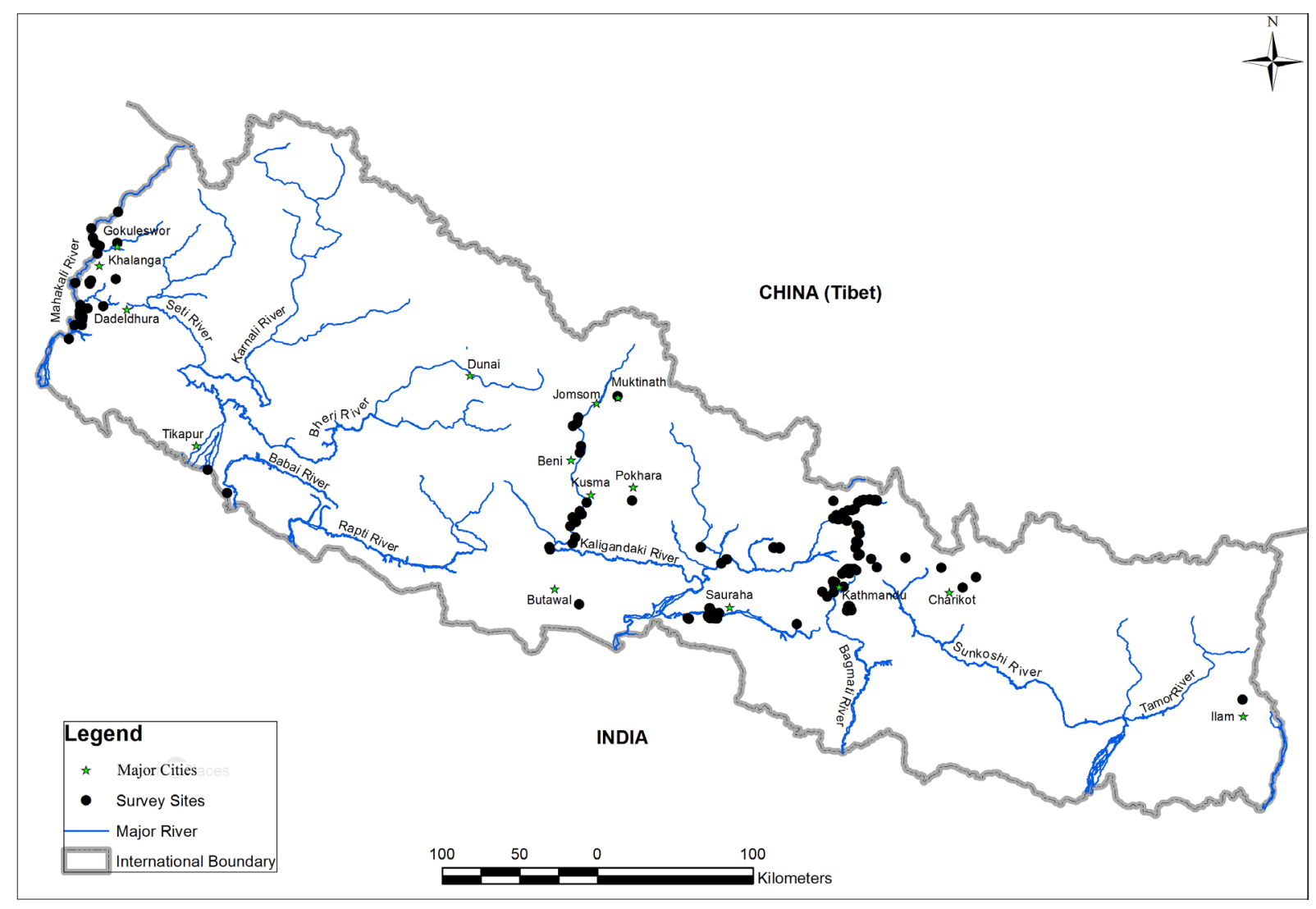

Fig.1. Map of the localities and areas surveyed for Diplommatina spp. in Nepal. 
- Tooth and lamella: all internal structures inside the shell are considered as lamella(e), while the term tooth is applied to the processus on the columellar lip visible through the aperture.

- Parietal lamella(e) or parietalis (Prt in Fig. 2B): a lamella on the sutural wall inside the shell. Inner parietal lamella or inner parietalis (Prt1): sutural lamella close to the columellar axis and the columellaris; Outer parietal lamella or outer parietalis (Prt2): sutural lamella further apart from the columellar axis.

- Palatal lamella(e) or palatalis (Fig. 2C): internal lamella on the roof of the body whorl close to the aperture. Horizontal palatalis (Hpt): internal lamella on the roof of the body whorl at the columellar side; Vertical palatalis (Vpt): internal lamella on the roof of the body whorl along or near the constriction that runs from the suture to the base.

- Peristome (Fig. 2A). Angular edge of the peristome (AeP): the edge between the parietal and palatal sides; Basal edge of the peristome (BeP): the edge between the basal and columellar sides; Columellar edge of the peristome $(\mathrm{CeP})$ : the edge between the basal and parietal sides; Parietal edge of the peristome (PeP): the edge between $\mathrm{BeP}$ and AeP.

\section{Morphological abbreviations}

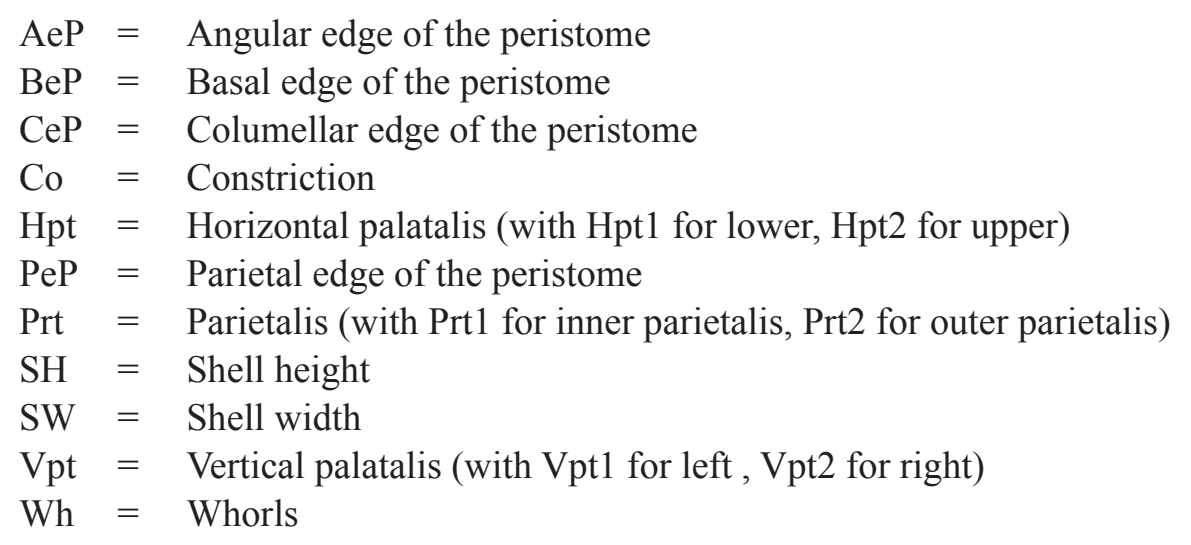

\section{Institutional abbreviations}

$\begin{array}{ll}\text { CDZMTU } & \text { Central Department Zoology Museum of Tribhuvan University, Nepal } \\ \text { NHM or NHMUK = } & \text { Natural History Museum, London, UK (NHMUK when citing registered } \\ & \text { specimens) }\end{array}$

\section{Results}

Class Gastropoda Cuvier, 1795

Order Caenogastropoda Cox, 1960

Family Diplommatinidae L. Pfeiffer, 1856

Genus Diplommatina Benson, 1849

Type species: Bulimus folliculus L. Pfeiffer, 1846.

\section{Diagnosis}

Height 1.3-8.0 mm. Sinistral or dextral; translucent (whitish in general). Protoconch generally smooth without radial ribs, but with evenly distributed minute pits all over. Teleoconch with radial ribs; spiral striation present or absent. Constriction at, near, or far apart from the parietal wall of the aperture. 


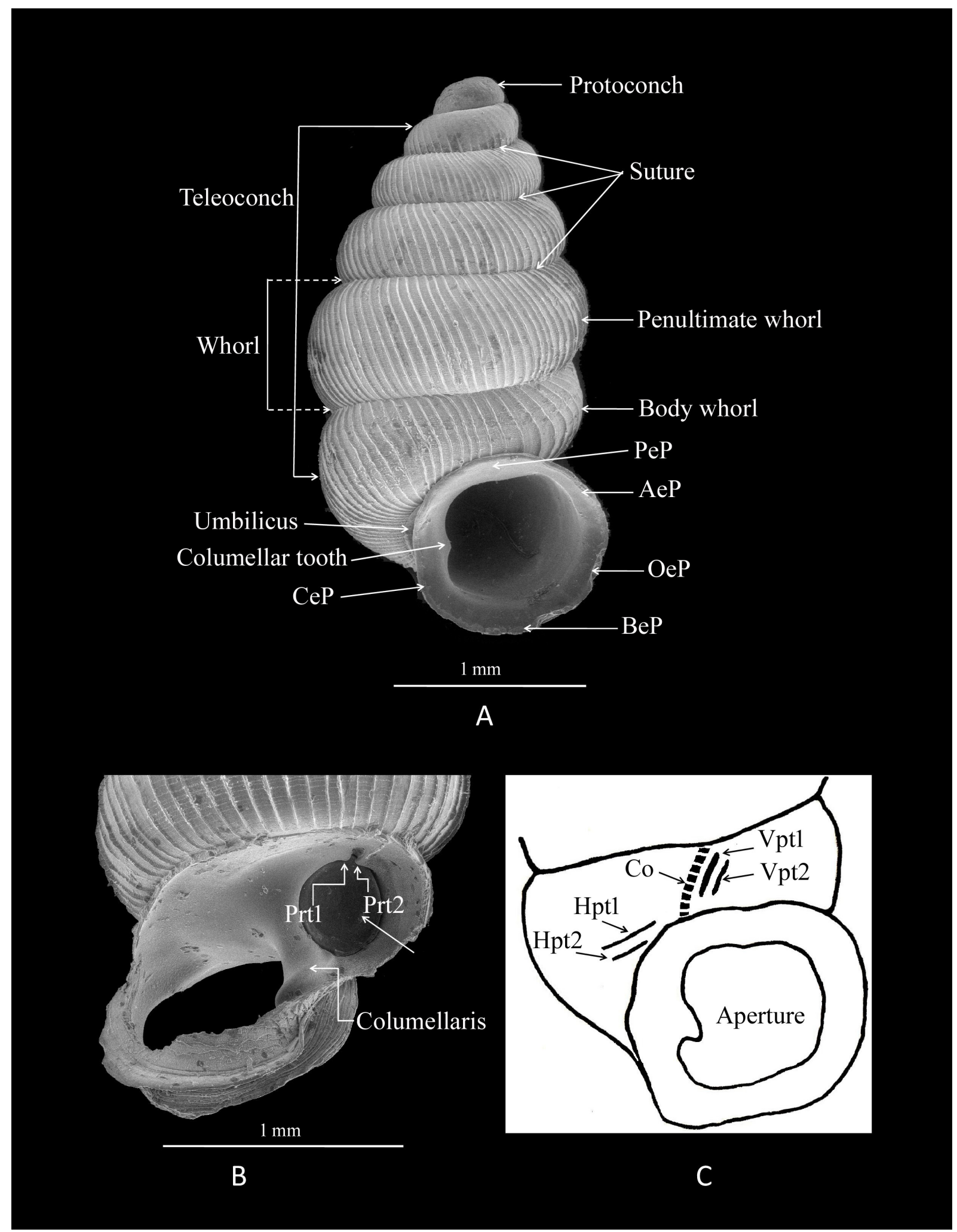

Fig. 2. Shell terminology. A. D. regularis Fulton, 1901. B. D. folliculus (L. Pfeiffer, 1846). C. General outline of the lower part of a shell from Diplommatina species. Abbreviations: Prt = Parietalis (Prt1 = inner parietalis, $\mathrm{Prt} 2=$ outer parietalis); $\mathrm{Pt}=$ Palatalis; $\mathrm{Hpt}=$ Horizontal palatalis $(\mathrm{Hpt} 1=$ lower, $\mathrm{Hpt} 2=$ upper in case of two); $\mathrm{Vpt}=$ Vertical palatalis $(\mathrm{Vpt} 1=$ left side, $\mathrm{Vpt} 2=$ right side in case of two). 
Internally ornamented with parietal and palatal lamellae and a columellaris. Columellar tooth strong, weak or absent. Aperture usually circular. Peristome with two lips. Operculum paucispiral.

\section{Type locality}

Pfeiffer (1846) described this species based on T. Hutton's material and erroneously mentioned "Bengal" as its type locality. The type material came from the vicinity of Simla (Himachal Pradesh, India), where

T. Hutton lived and where most of his material was collected (Godwin-Austen 1886).

Diplommatina abiesiana Budha \& Naggs sp. nov. urn:1sid:zoobank.org:act:F203B92F-6A52-4687-91DA-749554BB03AC

Figs 3A, 9A

\section{Diagnosis}

Measurements ( $\mathrm{n}=4$ ): SH 2.7-2.9 mm, SW 1.4-1.5 mm, Wh 6.0-6.5; holotype: SH 2.8 mm, SW $1.5 \mathrm{~mm}$, Wh 6.0. Dextral, penultimate whorl and body whorl nearly equal in width. Constriction at the middle of the parietal wall (Fig. 9A). Parietalis moderate, gradually elevated inner side of the body whorl. A short horizontal palatalis near the inner edge of the peristome. Columellaris moderately developed (Fig. 3A3). Columellar tooth weak. Protoconch smooth, Wh 1.5-2.0, with very minute evenly distributed pits, without radial ribs (Fig. 3A1). Teleoconch with dense radial ribs; $9-12$ ribs $/ 0.5 \mathrm{~mm}$ on the penultimate whorl; 7-9 ribs/0.5 mm on the body whorl towards the aperture (Fig. 3A2, A4). Spiral striation present. Umbilicus open. Aperture circular. Peristome with two lips; inner lip thin; 8-10 thin ribs between the two lips (Fig. 3A4). Parietal wall of the aperture extending to less than half the body whorl. Operculum paucispiral, corneous, thin, transparent, slightly concave, outer surface smooth, inner surface with weak ridge at the columellar margin.

\section{Etymology}

The species name refers to the habitat of the type locality, i.e., an Abies forest.

\section{Type material}

\section{Holotype}

NEPAL: Cholangpati, Langtang National Park, 3443 m, Abies forest, 28.110154 N, 85.334238 E, 19 May, R. Devkota and K. Saud leg. (CDZMTU020).

\section{Paratypes}

NEPAL: 3 shells from the type locality, same data as holotype (CDZMTU021); 8 shells, Baghdwar, 2314 m, Shivapuri-Nagarjun National Park, 27.8052 N, 85.38447 E, 24 Jun. 2007, P.B. Budha and R. Devkota leg. (CDZMTU055); 1 shell, Dhunche, 2056 m, Langtang National Park, 28.10894 N, 85.29155 E, 3 Jun. 2007, P.B. Budha leg. (CDZMTU056).

\section{Remarks}

The shell form of D. abiesiana is similar to that of D. nana W.T. Blanford, 1865 (Blanford 1865; Hanley \& Theobald 1876: pl. 140, fig.1; Godwin-Austen 1886: pl. 49, fig. 6.), but differs by its less prominent columellar tooth, the more widely-separated radial ribs, the penultimate and body whorls of equal width, and the circular aperture. 

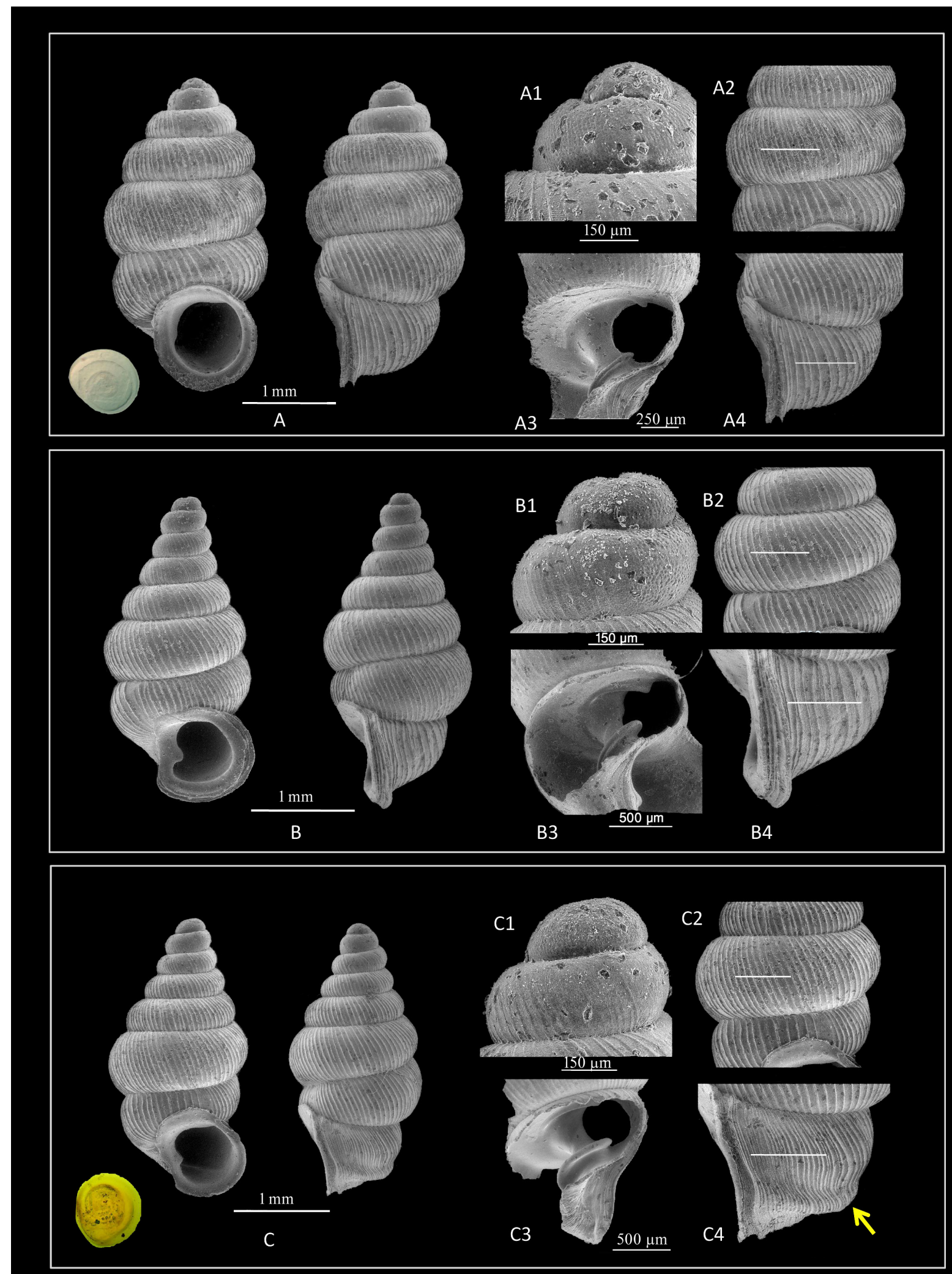

Fig. 3. Diplommatina Benson, 1849 of Nepal. A. D. abiesiana sp. nov., holotype (CDZMTU020). B. D. exserta Godwin-Austen, 1886 (CDZMTU024). C. D. fistulata sp. nov., holotype (CDZMTU025). The yellow arrow indicates the dorsal fold. Scale bar in images A2, A4, B2, B4, C2, C4 is $500 \mu \mathrm{m}$. 
Diplommatina exserta Godwin-Austen, 1886

Figs 3B, 9B

Diplommatina exserta Godwin-Austen, 1886: 184, pl. 49, figs 2, 2 a.

Diplommatina (Diplommatina) exserta - Kobelt 1902: 432.

Diplommatina exserta - Gude 1921: 314. — Budha et al. 2015: 6.

\section{Diagnosis}

Measurements $(\mathrm{n}=3)$ : SH 3.4-3.5 mm, SW 1.7-1.8 mm, Wh 7.5. Dextral, apical whorls slowly increasing in size, resulting in a slender conical spire. Penultimate and body whorls nearly equal in width. Constriction between parietal lips of the peristome at AeP (Fig. 9B). Two parietalis: Prt1 long and strongly developed, gradually elevated inner side of the body whorl, Prt2 short (Fig. 3B3). Two vertical palatalis: Vpt1 stronger and close to the constriction,Vpt2 short. One long horizontal palatalis, touching the inner parietal lip (Fig. 9B). Columellaris strong. Columellar tooth prominent. Protoconch smooth, Wh 2.0, with minute evenly distributed pits, no radial ribs (Fig. 3B1). Teleoconch with widely spaced radial ribs; $7-8 \mathrm{ribs} / 0.5 \mathrm{~mm}$ on the penultimate whorl; $8-10 \mathrm{ribs} / 0.5 \mathrm{~mm}$ on the body whorl towards the aperture (Fig. 3B2, B4). Ribs moderately prominent. Very fine spiral striation present. Umbilicus open. Aperture inversely C-shaped, due to the straight columellar edge of the lip. Peristome with two close lips; under high magnification 2-3 ribs seen between the two lips. Parietal wall of the aperture extending to nearly halfway up the body whorl.

\section{Material examined}

NEPAL: 4 shells, Siddha Cave, Tanahun, 695 m, 27.94544 N, 84.422244 E, 24 Oct. 2008, P.B. Budha and R. Devkota leg. (CDZMTU024).

\section{Remarks}

The most similar species are Diplommatina exilis W.T. Blanford, 1863 from Myanmar (Hanley \& Theobald 1876: pl. 119, fig.10) and D. pullula Benson, 1859 from "Rungun on the West of Darjiling" (Hanley \& Theobald 1876: pl. 119, fig.7). Compared to D. exserta, the apical whorls are wider in D. pullula and more tumid in D. exilis.

Diplommatina fistulata Budha \& Naggs sp. nov. urn:1sid:zoobank.org:act:CC722581-EC59-42AC-AD0F-EFD6247BD1A0

Figs 3C, 9C

\section{Diagnosis}

Measurements $(\mathrm{n}=10)$ : SH 3.0-3.3 mm, SW 1.5-1.8 mm, Wh 6.5-7.5; holotype: SH $3.3 \mathrm{~mm}$, SW $2.0 \mathrm{~mm}, \mathrm{Wh}$ 7.5. Dextral, body whorl narrower than penultimate whorl. Constriction at the middle of the parietal lip (Fig. 9C). Parietalis long and very strong (Fig. 3C3). Two vertical palatalis: a stronger Vpt1 along the constriction and a short Vpt2 running parallel to Vpt1 above the parietal wall (Fig. 9C). No horizontal palatalis. Columellaris prominent. Columellar tooth strong. Protoconch smooth, Wh 2.0, with minute pits scattered over the surface (Fig. $3 \mathrm{C} 1$ ). Teleoconch with dense radial ribs; $9-11 \mathrm{ribs} / 0.5 \mathrm{~mm}$ on the penultimate whorl; $15-20 \mathrm{ribs} / 0.5 \mathrm{~mm}$ on the body whorl towards the aperture (Fig. 3C2, C4). Distinct dorsal fold at base of body whorl, running towards the aperture (Fig. 3C4). Spiral striation present. Umbilical perforation visible, but umbilicus seems to be closed by the reflected edge of the columellar lip. Aperture ear-shaped, parietal wall oblique with regard to the coiling axis; peristome with two close lips; inner lip thickened and forming a thick callus over the parietal wall; under high 
magnification 12-15 highly dense ribs visible between the lips. Operculum paucispiral, corneous, thin, outer surface smooth, inner surface with thick peripheral circular edge.

\section{Etymology}

The species name refers to the tube-like structure of the dorsal fold on the body whorl just behind the aperture.

\section{Type material}

\section{Holotype}

NEPAL: Phulchowki Hill, Lalitpur District, 2308-2483 m, 27.574557 N, 85.400842 E, 4 May 2007, P.B. Budha leg. (CDZMTU025).

\section{Paratypes}

NEPAL: 5 shells from the type locality, same data as holotype (CDZMTU026); 4 shells, Baghdwar, Shivapuri-Nagarjun National Park, 2326 m, 27.8131 N, 85.4217 E, 22 Jun. 2007, P.B. Budha leg. (CDZMTU027a); 8 shells, Baghdwar area, Shivapuri-Nagarjun National Park, 2412-2502 m, 27.8233 N, 85.3877 E, 24-25 Apr. 2008, R. Devkota and P.B. Budha leg. (CDZMTU027b); 2 shells, Dhunche, Langtang National Park, 2056 m, 28.1087 N, 85.2916 E, 3-4 Jun. 2007, P.B. Budha leg. (CDZMTU057).

\section{Remarks}

Diplommatina fistulata sp. nov. resembles the NE Indian D. pachycheilus, from which it differs by its distinct dorsal fold behind the aperture, smaller size and more slender shape.

Diplommatina folliculus (L. Pfeiffer, 1846)

Figs 2B, 4A, 9D

Bulimus folliculus Pfeiffer, 1846: 83.

Bulimus folliculus - Pfeiffer 1848: 81-82.

Diplommatina folliculus - Godwin-Austen 1868: 83, pl.1, figs 1-2. - Hanley \& Theobald 1876: 56, pl. CXL, figs 8-9. — Gude 1921: 314. — Naggs 1997: 58.

Diplommatina (D.) folliculus - Ramakrishna et al. 2010: 86.

Diplommatina (Diplommatina) folliculus - Budha et al. 2015: p. 6.

\section{Diagnosis}

Measurements $(\mathrm{n}=15)$ : SH 2.6-3.0 mm, SW 1.2-1.4 mm, Wh 6.5-7.0. Dextral, penultimate whorl slightly wider than the body whorl. Constriction at the middle of the parietal wall (Fig. 9D). Internally with two parietal lamellae, both Prt 1 and Prt 2 very short, prominent at the lodging edge of the operculum (Figs 2B, 4A3). Two vertical palatal lamellae: Vpt1 along the constriction and Vpt2 short, but running parallel to Vpt1. No horizontal palatal lamella (Fig. 9D). Columellaris thin. Columellar tooth visible in the aperture. Protoconch smooth, Wh 1.5-2.0, with fine pits. Teleoconch with radial ribs visible only after the second whorl; widely spaced radial ribs; $6-7$ ribs $/ 0.5 \mathrm{~mm}$ on the penultimate whorl; 4-6 ribs $/ 0.5 \mathrm{~mm}$ on the body whorl towards the aperture (Fig. 4A2, A4). Spiral striation distinct. Umbilicus closed. Aperture circular. Peristome with two lips and expanded; lips widely spaced, sinuous at the angular edge. Outer lip slightly reflected. Operculum paucispiral, corneous, thin, transparent, slightly concave, outer surface smooth, inner surface with peripheral circular edge which is thicker at columellar margin. 

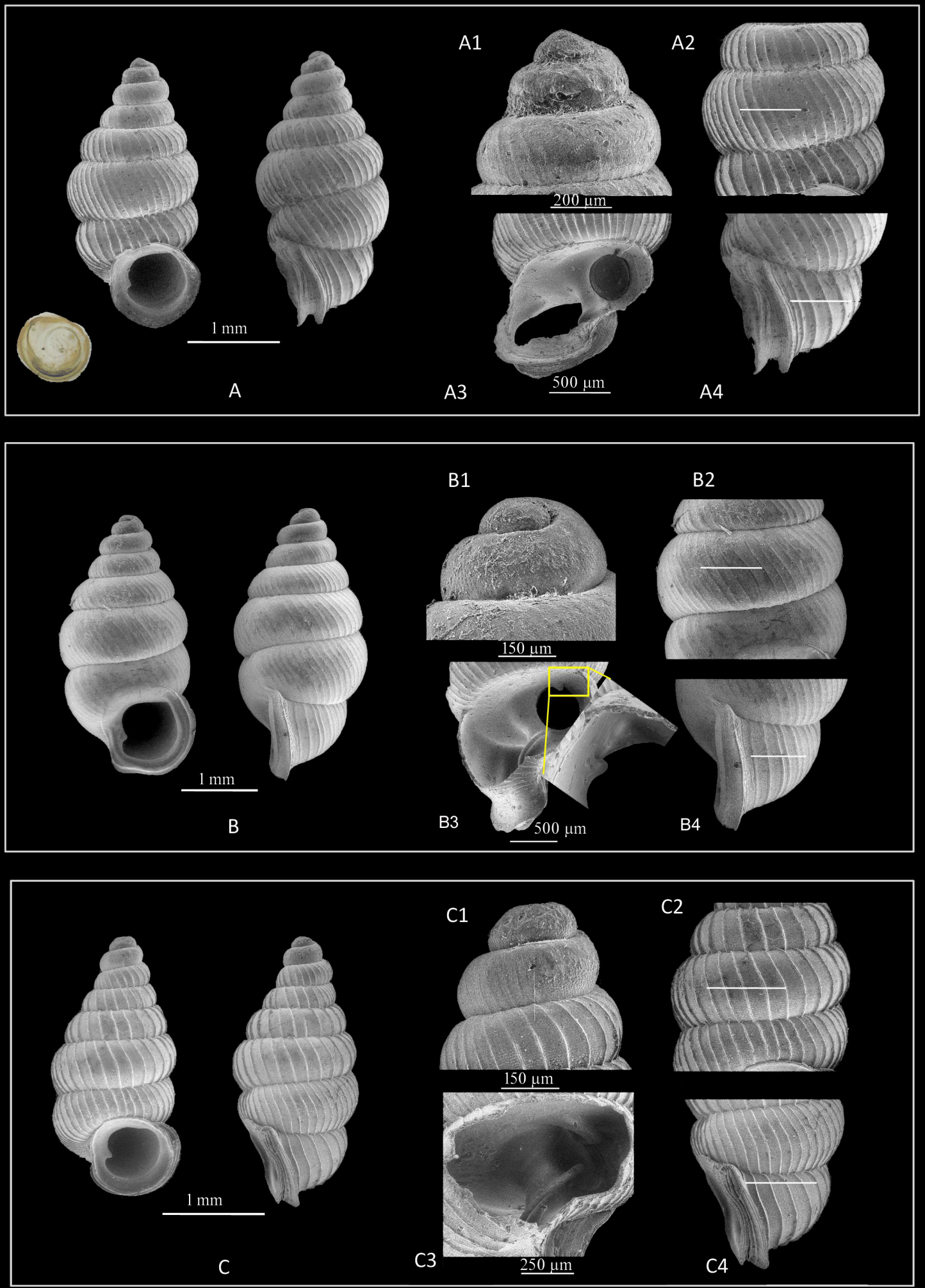

Fig. 4. Diplommatina Benson, 1849 of Nepal. A. D. folliculus (L. Pfeiffer, 1846) (CDZMTU028). B. D. godawariensis sp. nov., holotype (CDZMTU032). C. D. maipokhariensis sp. nov., holotype (CDZMTU034). Scale bar in images A2, A4, B2, B4, C2, C4 is $500 \mu \mathrm{m}$. 


\section{Material examined}

NEPAL: 80+ shells, Phulchowki Hill, Lalitpur District, 1551-2298 m, 27.580434 N, 85.387538 E, 3-11 May 2007, P.B. Budha leg. (CDZMTU028); 95 shells, Shivapuri-Nagarjun National Park, 23142716 m, 27.812591 N, 85.378807 E, 24-21 Jun. 2007, P.B. Budha leg. (CDZMTU029); 100+ shells, Shivapuri-Nagarjun National Park, 2314-2716 m, 27.812591 N, 85.378807 E, 24-26 Apr. 2008, P.B. Budha leg. (CDZMTU029b); 2 shells, Raniban, Balaju, Kathmandu, 1373 m, 27.7426 N, 85.2847E, 12 Mar. 2009, Srijana Khanal leg. (CDZMTU030); 100+ shells, Dhunche, Langtang National Park, 2056-2663 m, 28.106128 N, 85.303259 E, 2 Jun. 2007 and 11 May 2008, P.B. Budha and R. Devkota leg. (CDZMTU031).

\section{Remarks}

Diplommatina folliculus is a very common, abundant and distinct species that can be distinguished from the others by its strong, widely-spaced lips and costulated radial ribs. It is distributed from the western to the eastern Himalaya. The most similar species is D. silvicola Godwin-Austen, 1886 (pl. LXV, figs 3, 3a), but $D$. folliculus differs by its more slender shell and less distinct columellar tooth.

Diplommatina godawariensis Budha \& Naggs sp. nov. urn:lsid:zoobank.org:act:2ED01F49-7E8A-4A53-A021-720968DC721A

Figs 4B, 9E

\section{Diagnosis}

Measurements $(\mathrm{n}=5)$ : SH 3.2-3.5 mm, SW 1.7-1.8 mm, Wh: 6.5-7.0; holotype: SH $3.3 \mathrm{~mm}$, SW $1.8 \mathrm{~mm}$, Wh 7.0. Dextral, penultimate and body whorl nearly equal in width. Constriction at the inner edge of PeP (Fig. 9E). Two parietalis: Prt1 short and strong, Prt2 not very distinct, nearly attached to the sutural wall (Fig. 4B3). Two vertical palatalis, Vpt1 strong and runs along the constriction, Vpt2 short and small, difficult to distinguish, just above the outer lip of the parietal wall (Fig. 9E). Two horizontal palatalis: both Hpt1 and Hpt2 are thin, situated just above the columella, posterior longer than anterior (Fig. 9E). Columellaris distinct (Fig. 4B3). Columellar tooth prominent. Protoconch smooth, Wh approx. 2.0, with small pits evenly distributed, no radial ribs (Fig. 4B1). Teleoconch with radial ribs; about 5-6 ribs $/ 0.5 \mathrm{~mm}$ on the penultimate whorl; 5-7 ribs/ $0.5 \mathrm{~mm}$ on the body whorl towards the aperture (Figs 4B2, B4). No spiral striation. Umbilicus closed. Peristome with two lips; outer lip slightly reflected; inner lip thick and forming a thin callus on the penultimate whorl. Angular edge of the peristome rounded. Basal edge of the peristome outwardly directed.

\section{Etymology}

The species name refers to the type locality 'Godawari'.

\section{Type material}

\section{Holotype}

NEPAL: Godawari, Lalitpur District, 1551 m, mixed forest, 27.589284 N, 85.388309 E, 1 Dec. 2006, P.B. Budha leg. (CDZMTU032).

\section{Paratypes}

NEPAL: 5 shells from the type locality, same data as holotype (CDZMTU033); 2 shells, Godawari, 1551 m, 27.5969 N, 85.3890 E, 30 Apr. 2007, P.B. Budha leg. (CDZMTU033b). 


\section{Remarks}

Diplommatina godawariensis sp. nov. is similar to D. diplocheilus Benson, 1857 from Khasi Hills, NE India“"Teria Ghat, Khasi Hills" (Hanley \& Theobald 1876: pl. 140, figs 2-3), but D. godawariensis sp. nov. has a smaller columellar tooth and a narrower penultimate whorl. The aperture of D. godawariensis sp. nov. is rather similar to that of D. pachycheilus, but this latter species has more tumid apical whorls and its penultimate whorl is slightly narrower than that of $D$. godawariensis sp. nov.

Diplommatina maipokhariensis Budha \& Naggs sp. nov. urn:1sid:zoobank.org:act:EF1CC77A-F108-4578-B32E-7EBAF2F9EB22

Figs $4 \mathrm{C}, 9 \mathrm{~F}$

\section{Diagnosis}

Measurements $(\mathrm{n}=6)$ : SH 2.4-2.5 mm, SW 1.1-1.2 mm, Wh 7.2-7.5; holotype: SH $2.5 \mathrm{~mm}$, SW $1.1 \mathrm{~mm}, \mathrm{Wh}$ 7.5. Dextral, penultimate and body whorls nearly equal in width. Constriction at the inner edge of the parietal wall of the lip (Fig. 9F). Parietalis long and distinct (Fig. 4C3). Two vertical palatalis: Vpt1 distinct and strong, running along the constriction; Vpt2 thin, running parallel to Vpt1. Two horizontal palatalis running closely together giving the impression of a single lamella above the columella (Fig. 9F). Columellaris prominent. Columellar tooth distinct. Protoconch smooth, Wh approx. 2.0, with very distinct pits, without radial ribs (Fig. 4C1). Teleoconch with widely spaced strong radial ribs, evenly distributed on the penultimate and body whorls; about 4-6 ribs/0.5 mm (Figs 4C2, 4C4). Fine spiral striation present. Umbilicus closed. Aperture circular. Peristome with two widely spaced lips; 6-8 ribs between the lips (Fig. 4C4). Both lips slightly reflected.

\section{Etymology}

The species name refers to the type locality of Maipokhari, one of the Ramsar sites of Nepal.

\section{Type material}

\section{Holotype}

NEPAL: Maipokhari, Ilam, 2030 m, Cryptomeria forest, 27.001111 N, 87.92222 E, 25 Dec. 2010, P.B. Budha leg. (CDZMTU034).

\section{Paratypes}

NEPAL: 10 shells from the type locality, same data as holotype (CDZMTU035).

\section{Remarks}

The shell of Diplommatina maipokhariensis sp. nov. looks intermediate between the Philippine species D. concolor Quadras \& Möllendorff, 1893 (Zilch 1953: p. 28, fig. 156) and the Burmese (= Myanmar) species D. exilis W.T. Blanford, 1863 (Hanley \& Theobald 1876: pl. 119, fig. 10). Yet, it differs from both these species by its broader whorls. Diplommatina exilis also differs from D. maipokhariensis sp. nov. in the more slender shell and the absence of spiral striations.

Another slender species is D. exserta Godwin-Austen, 1886 (pl. 49, figs 2, 2a), which is larger and lacks a prominent constriction. The most similar species is D. pullula Benson, 1859 from Darjeeling, but D. maipokhariensis sp. nov. has stronger radial ribs and a smaller shell $(\mathrm{SH}<2.5 \mathrm{~mm})$ than D. pullula $(\mathrm{SH}>3 \mathrm{~mm})$. 
Diplommatina miriensis Godwin-Austen, 1917

Figs $5 \mathrm{~A}, 9 \mathrm{G}$

Diplommatina miriensis Godwin-Austen, 1917: 577, fig. 4D.

Diplommatina (Metadiancta) miriensis - Gude 1921, 342. — Ramakrishna et al. 2010: 95 Budha et al. 2015: 7.

\section{Diagnosis}

Measurements $(\mathrm{n}=5)$ : SH 1.5-1.6 mm, SW 0.8-1.0 mm, Wh 5.5. Dextral, whorls regularly increasing, penultimate and body whorl nearly equal in width. Constriction at the middle of the parietal wall (Fig. 9G). Parietalis very weak, nearly invisible (Fig. 5A3). One vertical palatalis along the constriction and one very strong horizontal palatalis just above the columella (Fig. 9G). Columellaris thin and weak. Columellar tooth very weak to nearly absent. Protoconch smooth, Wh approx. 1.5, with very distinct small pits evenly distributed all over, no radial ribs (Fig. 5A1). Teleoconch with dense radial ribs; about $10-13 \mathrm{ribs} / 0.5 \mathrm{~mm}$ on the penultimate whorl; $8-9 \mathrm{ribs} / 0.5 \mathrm{~mm}$ on the body whorl towards the aperture (Figs 5A2, 5A4). Very fine spiral striation present. Umbilicus closed. Aperture circular. Peristome with two lips; under high magnification 6-10 ribs visible between the lips (Fig. 5A4). Parietal wall with thin callus. Angular edge of the peristome curved (Fig. 5A3, A4); basal edge of peristome rounded; outer lip thin, inner lip thick. Parietal wall of the aperture hardly reaching half of the body whorl.

\section{Material examined}

NEPAL: 1 shell, Deurali, Syabru, Langtang National Park, 2412 m, 27.805037 N, 85.387862 E, 25 Apr. 2008, P.B. Budha leg. (CDZMTU036); 3 shells, Okhareni, Shivapuri-Nagarjun National Park, 2326 m, 27.813051 N, 85.4217 E, 22 Jun. 2007, R. Devkota and N. Kohar leg. (CDZMTU037); 1 shell, Baghdwar, Shivapuri-Nagarjun National Park, 2500 m, 27.8133 N, 85.3877 E, 25 Apr. 2008, P.B. Budha leg. (CDZMTU037b); 4 shells, Cholangpati, Langtang National Park, 3443 m, 28.110154 N, 85.334238 E, 19 May 2008, P.B. Budha leg. (CDZMTU038); 7 shells, Raniban, Balaju, Kathmandu, 1840-1902 m, 27.745997 N, 85.287240 E, 12 Mar. 2009, S. Khanal leg. (CDZMTU058).

\section{Remarks}

D. miriensis is the smallest species reported in the present study. Similar sized species are D. godwini Möllendorff, 1898 from Naga Hill, NE India, and the south Indian D. minima Beddome, 1875. Diplommatina godwini has more whorls ( $>7)$ than D. miriensis, while the peristome of D. minima has no curved angular edge.

Diplommatina munipurensis Godwin-Austen, 1892

Figs $5 \mathrm{~B}, 9 \mathrm{H}$

Diplommatina munipurensis Godwin-Austen, 1892: 518.

Diplommatina munipurensis - Godwin-Austen 1897: 14, pl. 66, fig. 6. — Gude 1921: 323.

Diplommatina (Diplommatina) munipurensis - Kobelt 1902: 438. — Budha et al. 2015: 7.

\section{Diagnosis}

Measurements $(\mathrm{n}=10)$ : SH 2.5-2.6 mm, SW 1.3-1.4 mm, Wh 6.0-6.5. Dextral, well rounded, regularly increasing, penultimate and body whorls nearly equal in width, suture impressed. Constriction at the middle of the parietal wall (Fig. 9H). One parietalis, moderate (Fig. 5B3). One vertical palatalis, which runs along the constriction, but does not reach the lower half of the whorl. No horizontal palatalis 

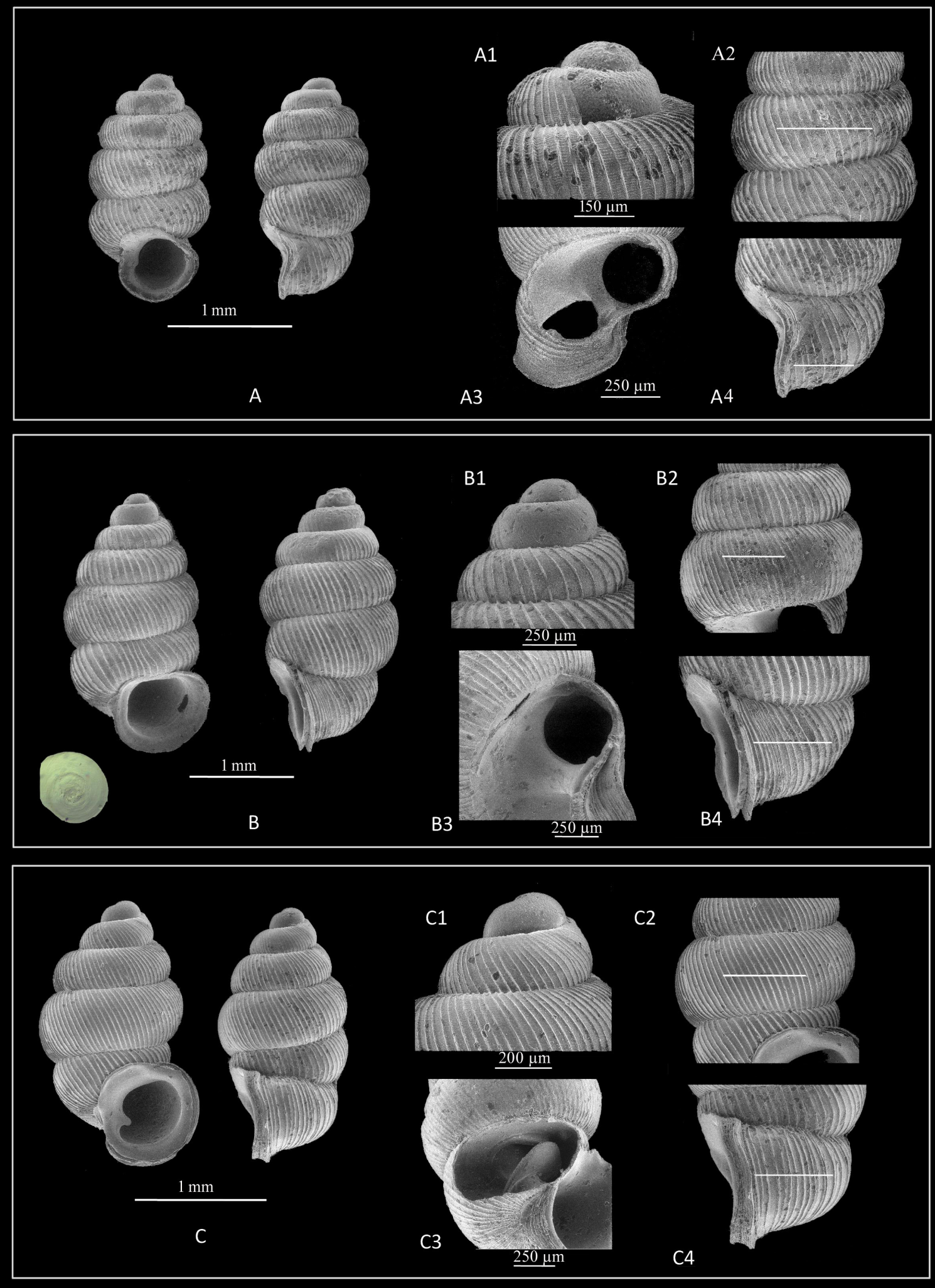

Fig. 5. Diplommatina Benson, 1849 of Nepal. A. D. miriensis Godwin-Austen, 1917 (CDZMTU036). B. D. munipurensis Godwin-Austen, 1892 (CDZMTU039). C. D. oviformis Fulton, 1901 (CDZMTU042). Scale bar in images A2, A4, B2, B4, C2, C4 is $500 \mu \mathrm{m}$. 
(Fig. 9H). Columellaris close to the umbilicus. Columellar tooth weak. Protoconch smooth, Wh approx 2.0, with small pits distributed all over, no radial ribs (Fig. 5B1). Teleoconch with dense radial ribs; about $8-10 \mathrm{ribs} / 0.5 \mathrm{~mm}$ on the penultimate whorl; $10-14 \mathrm{ribs} / 0.5 \mathrm{~mm}$ on the body whorl towards the aperture (Fig. 5B2, B4). Fine spiral striation present. Umbilicus closed. Aperture circular, parietal wall thin and straight. Peristome with two close lips; angular edge of the peristome straight; outer palatal lip rounded; basal lip along the columellar margin slightly curved; inner lip thin. Operculum paucispiral, corneous, thin, transparent, slightly concave, outer surface smooth, inner surface with raised edge at the central portion.

\section{Material examined}

NEPAL: 6 shells, Syabrubesi, above Lama Hotel, Langtang National Park, 2635 m, 28.197564 N, 85.455117 E, 13 May 2008, P.B. Budha leg. (CDZMTU039); 5 shells, Syabru, Langtang National Park, 3277 m, 28.105855 N, 85.326567 E, 6 Jun. 2007, P.B. Budha leg. (CDZMTU040); 7 shells, Phulchowki Hill, Lalitpur District, 2483 m, 27.57159 N, 85.401647 E, 4 May 2007, P.B. Budha leg. (CDZMTU041).

\section{Remarks}

Godwin-Austen (1892) gave the type locality as "South of the Barak River, between the Mao villages and Munipur" and noted that "from the number of specimens found, this appears a very abundant species; I never got anything like it in the Khasi Hills to the west".

\section{Diplommatina oviformis Fulton, 1901}

Figs 5C, 9I

Diplommatina oviformis Fulton, 1901: 203.

Diplommatina (Diplommatina) oviformis - Kobelt 1902: 440. — Gude 1921: 326. — Zilch 1953: 21, fig. 125. — Kuznetsov \& Schileyko 1997: 140. — Ramakrishna et al. 2010: 90. — Budha et al. 2015: 7.

\section{Diagnosis}

Measurements ( $\mathrm{n}=8$ ): SH 2.1-2.2 mm, SW 1.1-1.2 mm, Wh 6.0. Dextral, penultimate whorl wider than the body whorl. Constriction far behind the aperture (Fig. 9I). Two parietalis: Prt1 long and strong; Prt2 short (Fig. 5C3). One horizontal palatalis distinct, runs behind the aperture just above the suture from the constriction. Two vertical palatalis: Vpt1 prominent; Vpt2 thin, running parallel to Vpt1, but only over half its length (Fig. 9I). Columellaris well developed, occupying nearly half of the internal surface of the whorl. Columellar tooth strong (Fig. 5C3). Protoconch smooth, Wh 1.5, with minute evenly distributed pits (Fig. $5 \mathrm{C} 1$ ). Teleoconch with dense regular radial ribs; about $12-14$ ribs $/ 0.5 \mathrm{~mm}$ on the penultimate whorl; $9-12$ ribs $/ 0.5 \mathrm{~mm}$ on the body whorl towards the aperture (Fig. 5C2, C4). Spiral striation present. Umbilicus open. Aperture nearly quadruple. Peristome with two lips, slightly curved at the angular edge; parietal wall raised; inner lip thickened (Fig. 5C4). Both lips slightly reflected.

\section{Material examined}

Possible syntype

INDIA: 1 shell, [D. oviformis Fulton, 1901, Darjeeling, Sow. \& Ful. 01.10.1901] (RBINS 525545, MT1088).

\section{Other material examined}

NEPAL: 4 shells, Okhareni, Shivapuri-Nagarjun National Park, 2267-2326 m, 27.808762 N, 85.421615 E, 22 Jun. 2007, R. Devkota and N. Kohar leg. (CDZMTU042); 6 shells, Deurali, Langtang National Park, 2400-2412 m, 27.805037 N, 85.387862 E, 25 Apr. 2008, P.B. Budha leg. (CDZMTU043); 16 shells, 
Phulchowki Hill, Lalitpur District, 2308 m, 27.574557 N, 85.400842 E, 4 May 2007, P.B. Budha leg. (CDZMTU044); 2 shells, Raniban, Balaju, Kathmandu, 1780 m, 24 Jan. 2009, Srijana Khanal leg. (CDZMTU059).

\section{Remarks}

D. oviformis is a highly variable and very distinct species by its constriction far behind the aperture. This variability is illustrated by the following examples: the syntype shell from Darjiling in the NHM figured by Gude (1921: 326, fig. 36) has a nearly rounded parietal lip, whereas the shell figured by Zilch (1953: fig. 125, cotype SMF 105340, Darjiling, Himalaya) shows a slightly tilted parietal lip towards the columellar axis. Moreover, the apical whorls of the Nepalese shells reported here are comparatively wider than in the shells at NHM and RBINS (525545 from Darjeeling). The two lips of the peristome in the paratype at RBINS are closer to each other than in Nepalese shells. Nevertheless, for the time being we refer to the Nepalese shells as D. oviformis because of the typical constriction far behind the aperture.

Diplommatina pachycheilus Benson, 1857

Fig. 6

Diplommatina pachycheilus Benson, 1857: 203.

Diplommatina pachycheilus - Pfeiffer 1860: 143, pl. 37, figs 16-18. — Godwin-Austen 1868: 83, pl. 1, fig. 5. — Theobald 1876: 42. - Nevill 1878: 287.

Diplommatina pachycheila - Hanley \& Theobald 1876: pl. 140, figs 5-6.

Diplommatina (Diplommatina) pachychilus - Kobelt 1902: 440.

Diplommatina pachychilus - Gude 1921: 327. - Kuznetsov \& Schileyko 1997: 140. Ramakrishna et al. 2010: 90. — Budha et al. 2015: 7.

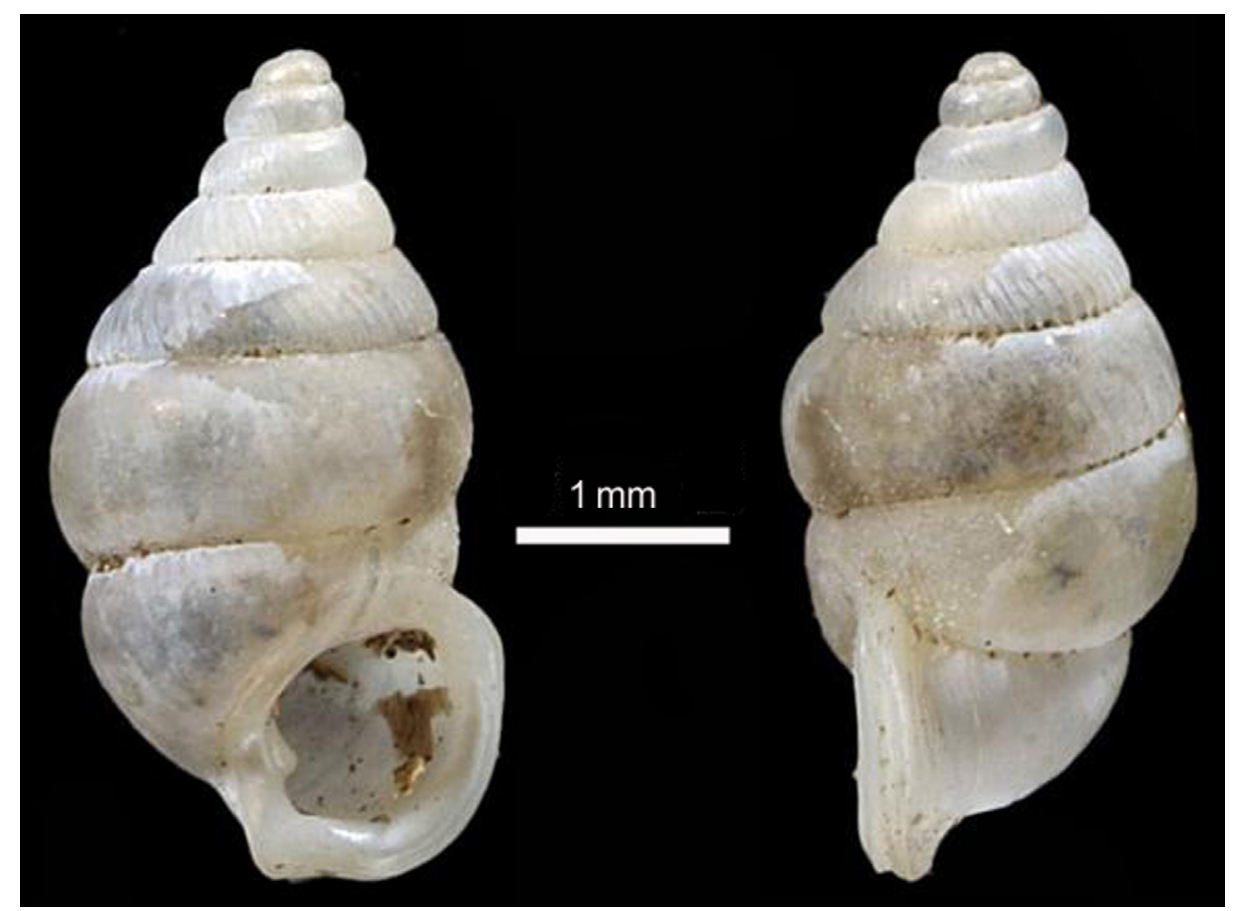

Fig. 6. Diplommatina pachycheilus Benson, 1857, specimen from Darjiling (one shell among five possible syntypes), [Teste H. Blanford] (UMZC I.102595, NHM). Image reproduced from Raheem et al. 2010) 


\section{Remarks}

The original spelling of the name is 'pachycheilus'. However, Kobelt (1902), Gude (1921), Kuznetsov \& Schileyko (1997), Ramakrishna et al. (2010) and Budha et al. (2015) spell it as 'pachychilus'. This is an unjustified emendation and the original spelling is restored here. This species was reported from Nepal by Kuznetsov \& Schileyko (1997), but it has been excluded from the identification key because Nepalese material was not available to examine internal lamellae. The Shivapuri-Nagarjun National Park was reported as a new distributional record for this species in Nepal by Budha et al. (2015). However, these records in fact refer to a new species described here, viz. D. fistulata sp. nov.

Diplommatina regularis Fulton, 1901

Figs 7A, 9J

Diplommatina regularis Fulton, 1901: 245.

Diplommatina regularis - Kobelt 1902: 442. — Gude 1921: 330.

Diplommatina (Diplommatina) regularis - Zilch 1953: 21, figs 125-126. - Ramakrishna et al. 2010: 91. - Budha et al. 2015: 7.

\section{Diagnosis}

Measurements $(\mathrm{n}=8)$ : SH 2.5-3.0 mm, SW 1.3-1.5 mm, Wh 7.0-7.5. Dextral, penultimate whorl slightly larger than the body whorl. Constriction at columellar margin slightly towards the inner lip of the parietal wall (Fig. 9J). One parietalis, short (Fig. 7A3). One vertical palatalis, parallel to the constriction. One short horizontal palatalis, situated just above the columella (Fig. 9J). Columellaris moderately thin. Columellar tooth weak, only visible in mature shells (Fig. 7A3). Protoconch smooth, with small pits distributed all over (Fig. 7A1). Teleoconch with regular radial ribs; about $8-11$ ribs $/ 0.5 \mathrm{~mm}$ on the penultimate whorl; 5-8 ribs $/ 0.5 \mathrm{~mm}$ on the body whorl towards the aperture (Fig. 7A2, A4). Very fine spiral striation present. Umbilicus closed. Outer lip at BeP abruptly curved on the columella, closing the umbilicus. Peristome thin, with two close lips (Fig. 7A4); AeP slightly curved, a single lip in most immature shells. Very thin parietal callus, extending at the base. Operculum paucispiral, corneous, thin, transparent, slightly concave, outer surface smooth, inner surface with raised peripheral circular edge.

\section{Material examined}

Possible syntype

INDIA: 1 shell [D. regularis Fulton, 1901 Darjeeling Sow. \& F. 01.10.1901 1/6] (RBINS 525556, MT1099).

\section{Other material examined}

NEPAL: 20 shells, Baghdwar, Shivapuri-Nagarjun National Park, 2314 m, 27.805203 N, 85.390029 E, 24 Jun. 2007, P.B. Budha leg. (CDZMTU045); 9 shells, Ghopte, Langtang National Park, 3419 m, 28.0193 N, 85.4619 E, 8 Jun. 2007, P.B. Budha leg. (CDZMTU060); 16 shells, Deurali, Langtang National Park, 3247-3277 m, 28.1059N, 85.3266 E, 6 Jun. 2007, P.B. Budha leg. (CDZMTU061).

\section{Remarks}

D. regularis is a very distinct species due to its regularly increasing whorls. Many shells with adult size show a single, very thin peristomal lip typical of juvenile shells. Juvenile shells show a more distinct constriction at the columellar margin than the fully grown shells. 

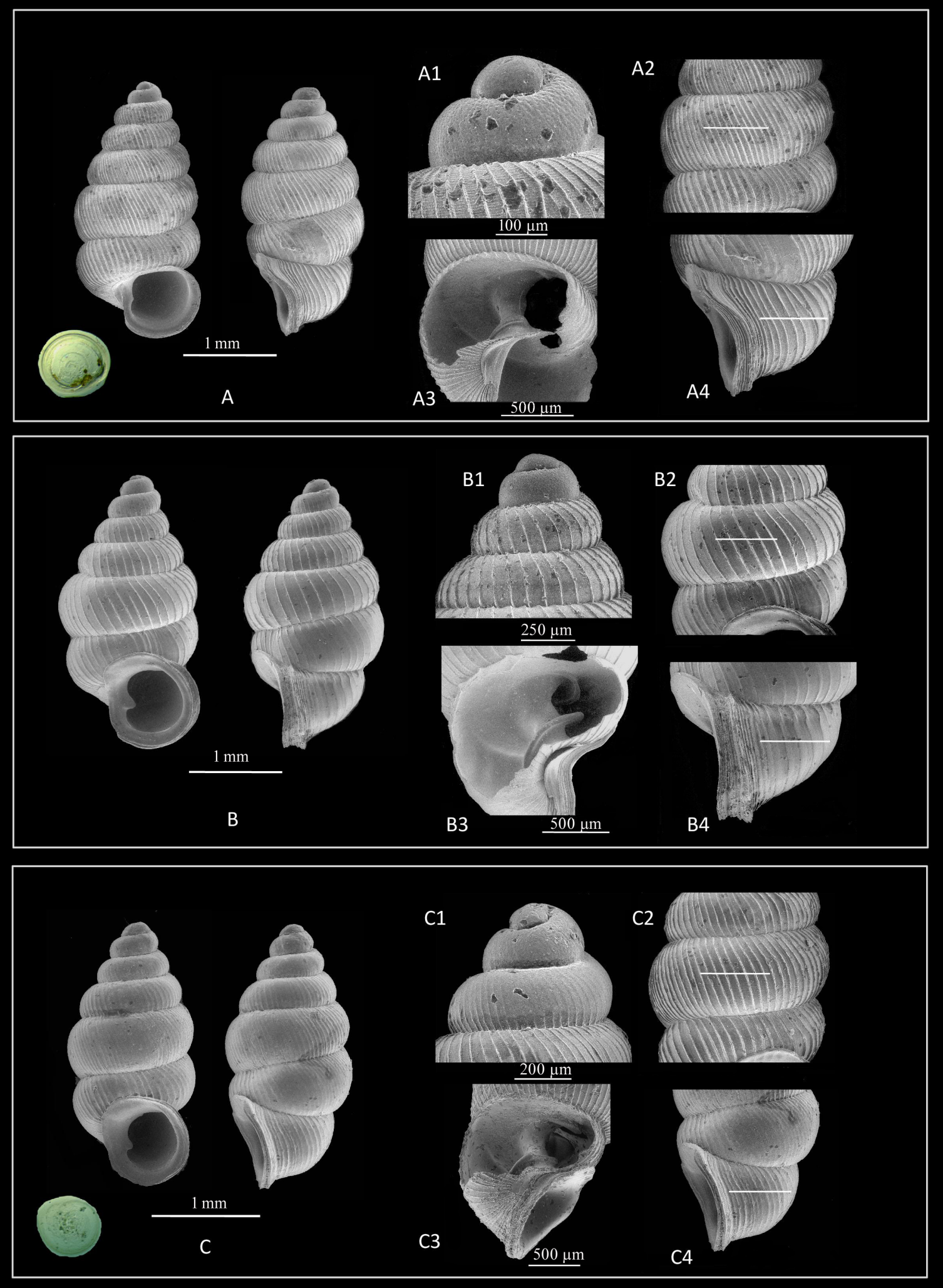

Fig. 7. Diplommatina Benson, 1849 of Nepal. A. D. regularis Fulton, 1901 (CDZMTU045). B. D. salgharica sp. nov., holotype (CDZMTU046). C. D. shivapuriensis sp. nov., holotype (CDZMTU048). Scale bar in images A2, A4, B2, B4, C2, C4 is $500 \mu \mathrm{m}$. 
Diplommatina salgharica Budha \& Backeljau sp. nov. urn:1sid:zoobank.org:act:3F0F16E7-C443-4184-A407-6FE45D74E5FD

Figs $7 \mathrm{~B}, 9 \mathrm{~K}$

\section{Diagnosis}

Measurements $(\mathrm{n}=8)$ : SH 2.8-3.1 mm, SW 1.5-1.6 mm, Wh 6.5-7.0; holotype: SH 3.0 mm, SW $1.5 \mathrm{~mm}$, Wh 7.0. Dextral, penultimate whorl wider than the body whorl. Constriction immediately at the right edge of PeP in between the two lips (Fig. 9K). Two parietalis: Prt1 long and prominent; Prt2 short, hardly visible (Fig. 7B3). One vertical palatalis running along the constriction. One horizontal palatalis (Fig. 9K). Columellaris prominent (Fig. 7B3). Columellar tooth distinct. Protoconch smooth, Wh approx. 2.0, with very fine pits (Fig. 7B1). Teleoconch with very strong and widely spaced radial ribs; about 4-6 ribs $/ 0.5 \mathrm{~mm}$ on the penultimate whorl; $7-8 \mathrm{ribs} / 0.5 \mathrm{~mm}$ on the body whorl towards the aperture (Fig. 7B2, B4). Spiral striation present, but very weak and hardly visible. Umbilicus open, nearly covered by the outer lip. Aperture circular. Parietal wall of aperture slightly oblique along the coiling axis. Peristome with two close lips, inner lip slightly thickened and reflected; basal lip angular along the columella. Parietal wall of aperture extending beyond half the body whorl.

\section{Etymology}

The species name refers to Salghari in Nepali, meaning Sal tree (Shorea robusta) forest, indicating the habitat from which the species was collected.

\section{Type material}

\section{Holotype}

NEPAL: Siddha Cave, Tanahun District, 695 m, Shorea robusta forest, 27.94544 N, 84.422244 E, 1 Apr. 2008, P.B. Budha leg. (CDZMTU046).

\section{Paratypes}

NEPAL: 50 shells from the type locality, same data as holotype (CDZMTU047); 10 shells from the type locality, 4 Oct. 2008, P.B. Budha leg. (CDZMTU047b).

\section{Remarks}

Diplommatina salgharica sp. nov. is very similar to D. exserta (see Godwin-Austen 1886: pl. 49, figs 2, 2a), but is easily distinguished by its less tumid apical whorls and the presence of two parietal teeth. The constriction is nearly at the middle of the parietal lip in $D$. exserta, i.e., at the right edge of the peristome immediately to the parietal lip of the aperture.

\section{Diplommatina shivapuriensis Budha \& Backeljau sp. nov. urn:1sid:zoobank.org:act:76F83F52-F806-48D2-A61F-57C5BA4A2E29}

Figs 7C, 9L

\section{Diagnosis}

Measurements ( $=8$ ): SH 2.5-3.0 mm, SW 1.2-1.3 mm, Wh 6.5-7.0; holotype: SH 2.9 mm, SW $1.4 \mathrm{~mm}$, Wh 6.5. Dextral, penultimate and body whorl nearly equal, constriction at the middle of the parietal lip (Fig. 9L). Two parietalis: Prt1 long and well developed; Prt2 short and hardly visible (Fig. 7C3). One vertical palatalis along the constriction. One horizontal palatalis before the constriction, just above the umbilicus (Fig. 9L). Columellaris prominent. Protoconch smooth, Wh approx. 2.0, with minute pits evenly distributed, no radial ribs (Fig. 7C1). Teleoconch with radial ribs; about $8-10$ ribs $/ 0.5 \mathrm{~mm}$ on the penultimate whorl; $10-13 \mathrm{ribs} / 0.5 \mathrm{~mm}$ on the body whorl towards the aperture (Fig. 7C2, C4). Spiral 
striation present. Umbilicus closed. Aperture circular. Peristome slightly curved at AeP, two lips, closer at angular edge. Parietal lip of the peristome slightly raised. Both lips slightly reflected. Operculum paucispiral, corneous, thin, transparent, slightly concave, outer surface smooth, inner surface with weakly raised peripheral circular edge.

\section{Etymology}

The species name refers to the Shivapuri peak from where it was collected.

\section{Type material}

\section{Holotype}

NEPAL: Shivapuri-Nagarjun National Park, $200 \mathrm{~m}$ below Shivapuri peak above Baghdwar, $2500 \mathrm{~m}$, 27.813284 N, 85.387712 E. 25 Apr. 2008, P.B. Budha leg. (CDZMTU048).

\section{Paratypes}

NEPAL: 50 shells from the type locality, same data as holotype (CDZMTU049); 6 shells from Deurali, Phobrang, Langtang National Park, 3247 m, 28.1057 N, 85.3263 E, 6 Jun. 2007, P.B. Budha leg. (CDZMTU049b).

\section{Remarks}

Diplommatina shivapuriensis sp. nov. is similar to D. sherfaiensis Godwin-Austen, 1870 from Sherborsip, Jaintia Hill, India (RBINS Dautzenberg collection I.G. 10591, 6 shells). Yet, D. shivapuriensis sp. nov. has a thinner shell, with a constriction in the middle (in D. sherfaiensis the constriction is more towards the columellar edge). The horizontal palatalis is widely separated from the parietal wall in $D$. sherfaiensis (see image ID 1903.7.1.2254 at www.nhm.ac.uk), but closer to the parietal wall in D. shivapuriensis sp. nov.

Diplommatina silvicola Godwin-Austen, 1886

Figs $8 \mathrm{~A}, 9 \mathrm{M}$

Diplommatina (Diplommatina) silvicola Godwin-Austen, 1886: 178.

Diplommatina (Diplommatina) silvicola - Gude 1921: 335. — Ramakrishna et al. 2010: 92. Budha et al. 2015: 7.

\section{Diagnosis}

Measurements (n = 7): SH 2.3-2.5 mm, SW 1.2-1.3 mm, Wh 6.0-6.5. Dextral, penultimate and body whorls nearly equal in width, constriction at the middle of the parietal lip above the aperture (Fig. 9M). One long parietalis (Fig. 8A3). One vertical palatalis. Horizontal palatalis absent (Fig. 9M). Columellaris prominent. Columellar tooth distinct. Protoconch smooth, Wh 1.5, with minute pits, radial ribs absent (Fig. 8A1). Teleoconch with strong, widely spaced radial ribs, about $4-6 \mathrm{ribs} / 0.5 \mathrm{~mm}$ on the penultimate whorl; 5-7 ribs $/ 0.5 \mathrm{~mm}$ on the body whorl towards the aperture (Fig. 8A2, A4). Spiral striation distinct. Umbilicus closed. Aperture circular. Peristome usually simple, but with two lips in some adult shells; inner lip very thick and elevated. Columellar margin of the peristome straight. Parietal wall of aperture not extending to the body whorl.

\section{Material examined}

\section{Possible syntype}

INDIA: 1 shell, [D. silvicola Godwin-Austen 1886 Jatinga Valley, N. Cachar, India. W.F. Webb, ex. coll. Godwin-Austen 06.07.1928] (RBINS 525561, MT 1104). 

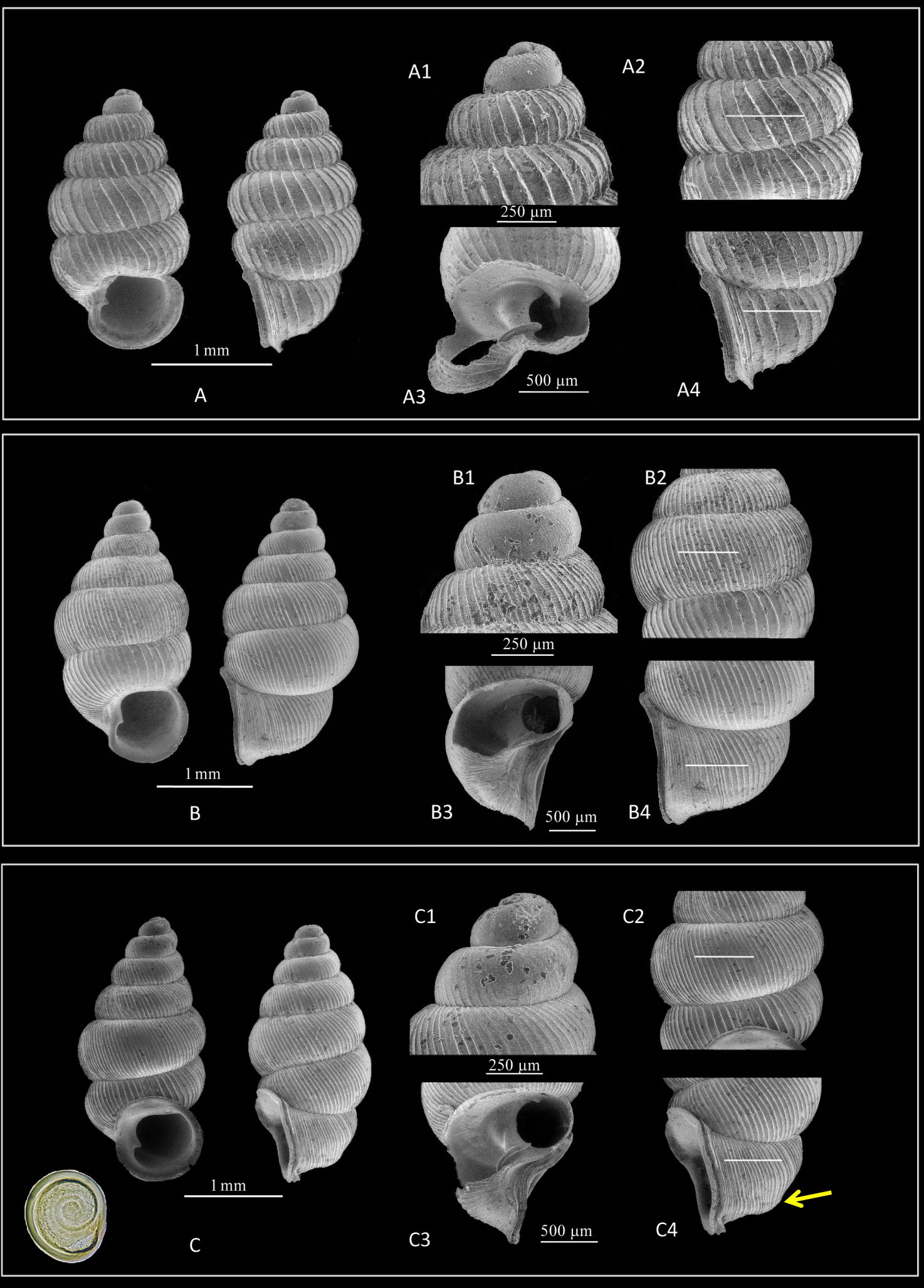

Fig. 8. A. Diplommatina silvicola Godwin-Austen, 1886 (CDZMTU050). B. D. sperata W.T. Blanford, 1862 (CDZMTU062). C. D. syabrubesiensis sp. nov., holotype (CDZMTU051). The yellow arrow indicates the dorsal fold. Scale bar in images A2, A4, B2, B4, C2, C4 is $500 \mu \mathrm{m}$. 


\section{Other material examined}

NEPAL: 11 shells, Panitanki, Balaju, Kathmandu at the base of a sandstone hill, Shivapuri-Nagarjun National Park, 1356 m, 27.736501 N, 85.298484 E, 14 Apr. 2008, P.B. Budha leg. (CDZMTU050); 2 shells, Raniban, Balaju, Kathmandu, 1780-1820 m, 27.745997 N, 85.287240 E, 4 Jan. 2009, Srijanal Khanal leg. (CDZMTU050b).

\section{Remarks}

Diplommatina silvicola is a very distinct species due to its ovate and transparent shell.

Diplommatina sperata W.T. Blanford, 1862

Figs $8 \mathrm{~B}, 9 \mathrm{~N}$

Diplommatina sperata W.T. Blanford, 1862: 143.

Diplommatina sperata - Nevill 1878: 284. — Godwin-Austen 1886: 179, pl. 44, figs 5, 5a. Kuznetsov \& Schileyko 1997: 140.

\section{Diagnosis}

Measurements ( $\mathrm{n}=3$ ): SH 3.0-3.2 mm, SW 1.5-1.7 mm, Wh 7.0. Dextral, penultimate whorl and the body whorl nearly equal in width, constriction at the middle of the parietal lip above the aperture (Fig. 9N). One parietalis, distinct towards the aperture (Fig. 8B3). One vertical palatalis along the constriction. Horizontal palatalis absent (Fig. 9N). Columellaris weak. Columellar tooth distinct. Protoconch smooth, Wh 1.5-2.0, with minute pits evenly distributed, radial ribs absent (Fig. 8B1). Teleoconch with strong, widely spaced, radial ribs; about $8-10$ ribs $/ 0.5 \mathrm{~mm}$ on the penultimate whorl; $13-16$ ribs $/ 0.5 \mathrm{~mm}$ on the body whorl towards the aperture (Fig. 8B2, B4). Spiral striation distinct. Umbilicus open. Aperture circular. Peristome with two close lips; under high magnification 6-8 thin ribs seen between the lips; basal columellar lip slightly directed towards the columella. Parietal wall of aperture not reaching the middle of the body whorl.

\section{Material examined}

NEPAL: 2 shells, Deurali, Langtang National Park, 2621 m, 28.1038 N, 85.3248 E, 5 Jun. 2007, P.B. Budha leg. (CDZMTU062); 1 shell, Baghdwar, Chapali, Shivapuri-Nagarjun National Park, 2532 m, 27.8125 N, 85.3919 E, 23 Jun. 2007, P.B. Budha leg. (CDZMTU063).

\section{Remarks}

Diplommatina sperata was originally described by Blanford (1862) from Myanmar ("in montibus Arakan a Pegu secernentibus"), but Kuznetsov \& Schileyko (1997) reported this species from steep rocks in dense bushes in the Solukhumbu District, eastern Nepal. Nepalese shells are thinner than the alleged syntypes in NHM and have much thinner peristomal lips. Nevertheless, we provisionally assign the above Nepalese shells to $D$. sperata.

Diplommatina syabrubesiensis Budha \& Backeljau sp. nov. urn:Isid:zoobank.org:act:1CFD0C16-38F3-489C-9A86-945A6475250B

Figs $8 \mathrm{C}, 9 \mathrm{O}$

\section{Diagnosis}

Measurements $(\mathrm{n}=11)$ : SH 2.9-3.2 mm, SW 1.4-1.5 mm, Wh 6.5-7.0; holotype: SH $3.2 \mathrm{~mm}$, SW $1.5 \mathrm{~mm}$, Wh 7.0. Dextral, whorls regularly increasing, penultimate whorl slightly wider than the body 
whorl, suture impressed, constriction nearly at the middle in front of the parietal wall (Fig. 90). One weak parietalis (Fig. 8C3). One vertical palatalis. Horizontal palatalis absent (Fig. 9O). Columellaris moderate, weak towards the aperture. Protoconch smooth, with minute pits evenly distributed, radial ribs absent (Fig. 8C1). Teleoconch with distinct radial ribs; $9-11 \mathrm{ribs} / 0.5 \mathrm{~mm}$ on the penultimate whorl; 13-16 ribs $/ 0.5 \mathrm{~mm}$ on the body whorl towards the aperture. Dorsal fold present, but weakly developed (Fig. 8C2, C4). Spiral striation present, but hardly visible. Umbilicus closed. Aperture circular; parietal wall thick, raised and slightly oblique with regard to the coiling axis. Peristome with two slightly spaced lips; angular edge of the peristome straight; palatal lip rounded; basal lip along the columellar margin slightly curved; inner lip slightly thickened and forming a thick callus over the parietal wall. Operculum paucispiral, Wh 2.5, outer whorl comparatively wide.

\section{Etymology}

The species name refers to the type locality 'Syabrubesi'.

\section{Type material}

\section{Holotype}

NEPAL: Syabrubesi, above Lama Hotel, Langtang National Park, 2635 m, 28.197564 N, 85.455117 E, 13 May 2008, P.B. Budha leg. (CDZMTU051).

\section{Paratypes}

NEPAL: 7 shells from the type locality, same data as holotype (CDZMTU052); 27 shells, Dhunche, Langtang National Park, 2056 m, 28.108942 N, 85.291547 E, 3 Jun. 2007, P.B. Budha leg. (CDZMTU053); 2 shells, Baghdwar-Deurali trek, Shivapuri-Nagarjun National Park, 2406 m, 27.803775 N, 85.38872 E, 25 Apr. 2008, P.B. Budha leg. (CDZMTU054).

\section{Remarks}

The shell of D. syabrubesiensis sp. nov. is similar to that of $D$. fistulata sp. nov. However, the peristome of $D$. fistulata sp. nov. is highly tilted towards the left on the inner wall of the parietal lip on the columellar axis, while it is round in D. syabrubesiensis sp. nov. Moreover, D. fistulata sp. nov. has a strong dorsal fold, which is not distinct in $D$. syabrubesiensis sp. nov and only visible through careful observation (see Fig. 8C4).

\section{Key to the Nepalese Diplommatina species}

A key to 15 species of Diplommatina is provided. Two species of Diplommatina (D. canarica and D. pachycheilus) reported by Kuznetsov \& Schileyko (1997) were excluded from the key because neither species were found in the present surveys and no Nepalese material was available to examine internal lamellae. Moreover, D. canarica is endemic in the Western Ghats (Raheem et al. 2014).

1. Spiral striation present

- Spiral striation absent, constriction at the left side of the parietal edge of the aperture (Fig. 8E), presence of two parietalis (Prt1 and Prt2), two vertical palatalis (Vpt1 and Vpt2) and two horizontal palatalis (Hpt1 and Hpt2)

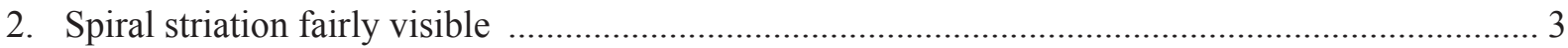

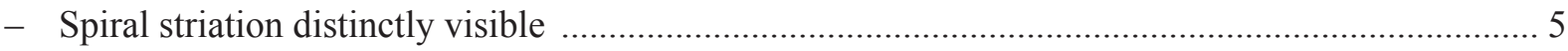

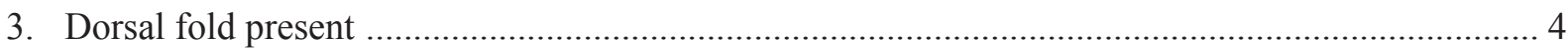

- Dorsal fold absent, constriction at AeP (Fig. 9M), parietal wall slightly tilted left (Fig. 7C) 
4. Dorsal fold distinct (Fig. 3C4)

D. fistulata $\mathrm{sp}$. nov

- Dorsal fold fairly distinct (Fig. 8C4) D. syabrubesiensis sp. nov

5. Radial ribs widely spaced, $5-10 \mathrm{ribs} / 0.5 \mathrm{~mm}$ 6

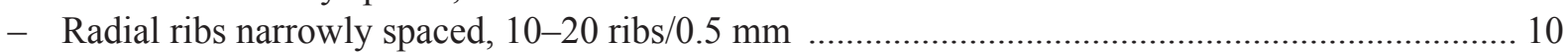

6. Constriction at the middle of the parietal wall of the peristome ….................................................. 7

- Constriction not at the middle of the parietal wall of the peristome ............................................... 8

7. Two short parietalis (Prt1 and Prt2) (Fig. 2B), columellaris moderate (Fig. 4A3)

D. folliculus (L. Pfeiffer, 1846)

- One long parietalis, columellaris strong (Fig. 8A3) D. silvicola Godwin-Austen, 1886

8. Constriction in the left side of PeP, two short horizontal palatalis (Hpt1 and Hpt2) (Fig. 9F)

D. maipokhariensis sp. nov

- Constriction in the right side of PeP

9. Apical whorls slender (Fig. 3B), one parietalis

D. exserta Godwin-Austen, 1886

- Apical whorls not slender (Fig. 4B), two parietalis (Prt1 and Prt2) (Fig. 9B)

D. salgharica $\mathrm{sp}$. nov

10. Constriction near or at the center of PeP .11

- Constriction not at the center of PeP 14

11. Horizontal palatalis present 12

- Horizontal palatalis absent 13

12. AeP straight (Fig. 3A), parietalis thin and long (Fig. 3A3) D. abiesiana sp. nov

- AeP curved (Fig. 5A, A4), parietalis very weak, nearly invisible

D. miriensis Godwin-Austen, 1917

13. Penultimate whorl slightly larger than body whorl, columellar tooth distinct (Fig. 8B) ...................................................................................... s. sperata W.T. Blanford, 1862

- Penultimate whorl and body whorl nearly equal, columellar tooth not distinct (Fig. 5B) D. munipurensis Godwin-Austen, 1892

14. Constriction at the left side from the center of the PeP (Fig. 9J), AeP curved (Fig. A4), short horizontal palatalis (Fig. 9J)

D. regularis Fulton, 1901

- Constriction far ahead from the aperture, very long horizontal palatalis and two vertical palatalis (Vpt1 and Vpt2) (Fig. 9I) D. oviformis Fulton, 1901

\section{Discussion}

There was a long debate between Gray $(1853,1855)$ and Benson $(1852,1853 \mathrm{a}, 1853 \mathrm{~b})$ about the presence/absence of an operculum in D. folliculus. William Benson (1855) finally observed the operculum and accepted Gray's (1850) opinion to place Diplommatina in Cyclophoridae (and later in the Diplommatinidae). W.T. Blanford (1867) was the first to illustrate the animal with its eyes and operculum, while Macdonald (1869) provided details on the anatomy of the genus Diplommatina and discussed its affinities with Cyclophoridae. But the lamellar system of the Himalayan Diplommatina is largely unknown. Naggs (1997) published a SEM photograph of the shell of D. folliculus collected by Hutton. This shell shows radial ribs, a columellaris and a parietal lamella (see Fig. 10), which are further detailed in this paper. 

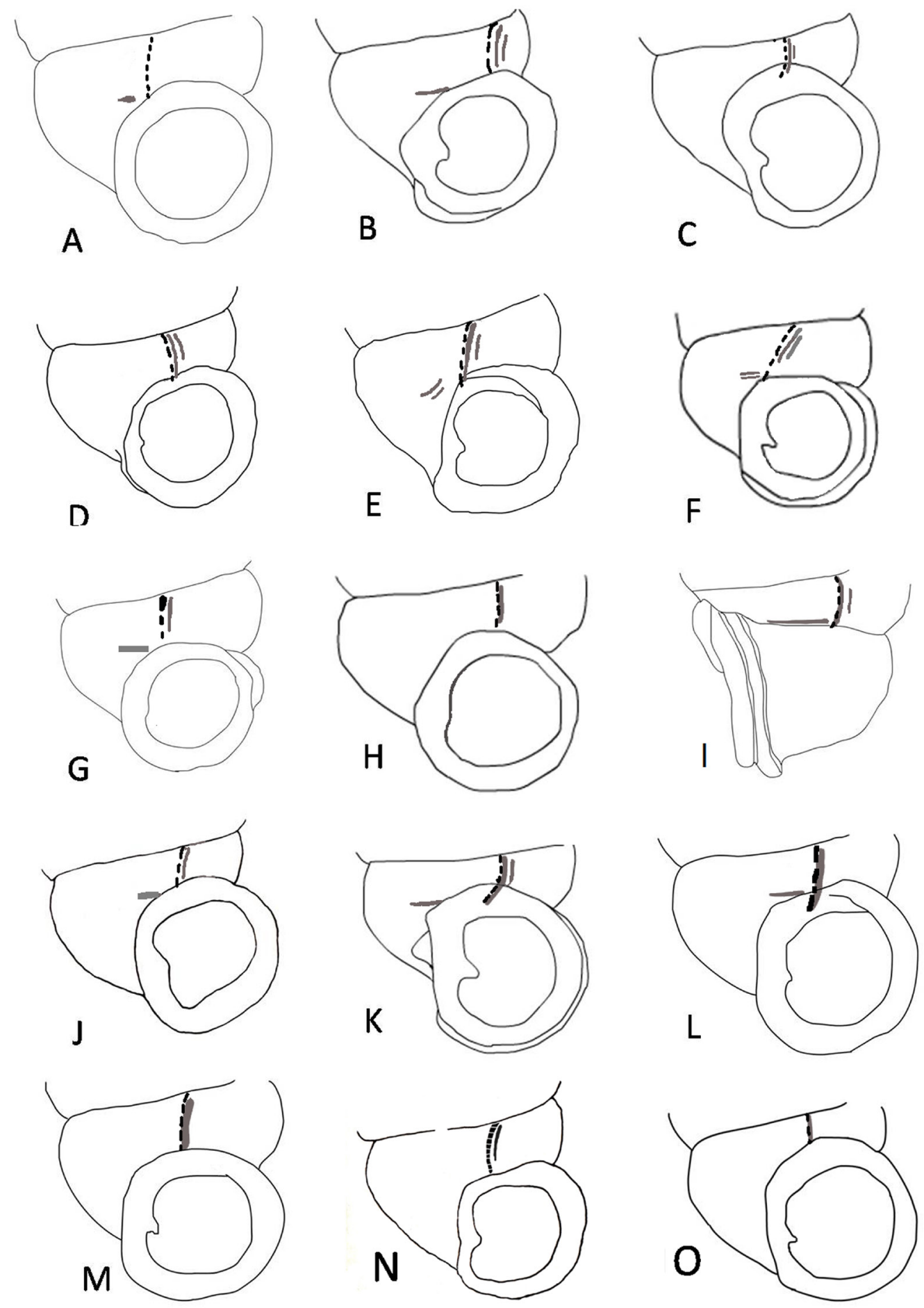

Fig. 9. Palatal lamellae (palatalis) of species of Diplommatina. Dotted lines indicate the position of the constriction. Dark lines indicate the palatalis. A. D. abiesiana sp. nov. B. D. exserta GodwinAusten, 1886. C. D. fistulata sp. nov. D. D. folliculus (L. Pfeiffer, 1846). E. D. godawariensis sp. nov. F. D. maipokhariensis sp. nov. G. D. miriensis Godwin-Austen, 1917. H. D. munipurensis GodwinAusten, 1892. I. D. oviformis Fulton, 1901. J. D. regularis Fulton, 1901. K. D. salgharica sp. nov. L. D. shivapuriensis sp. nov. M. D. silvicola Godwin-Austen, 1886. N. D. sperata W.T. Blanford, 1862. O. D. syabrubesiensis sp. nov. 


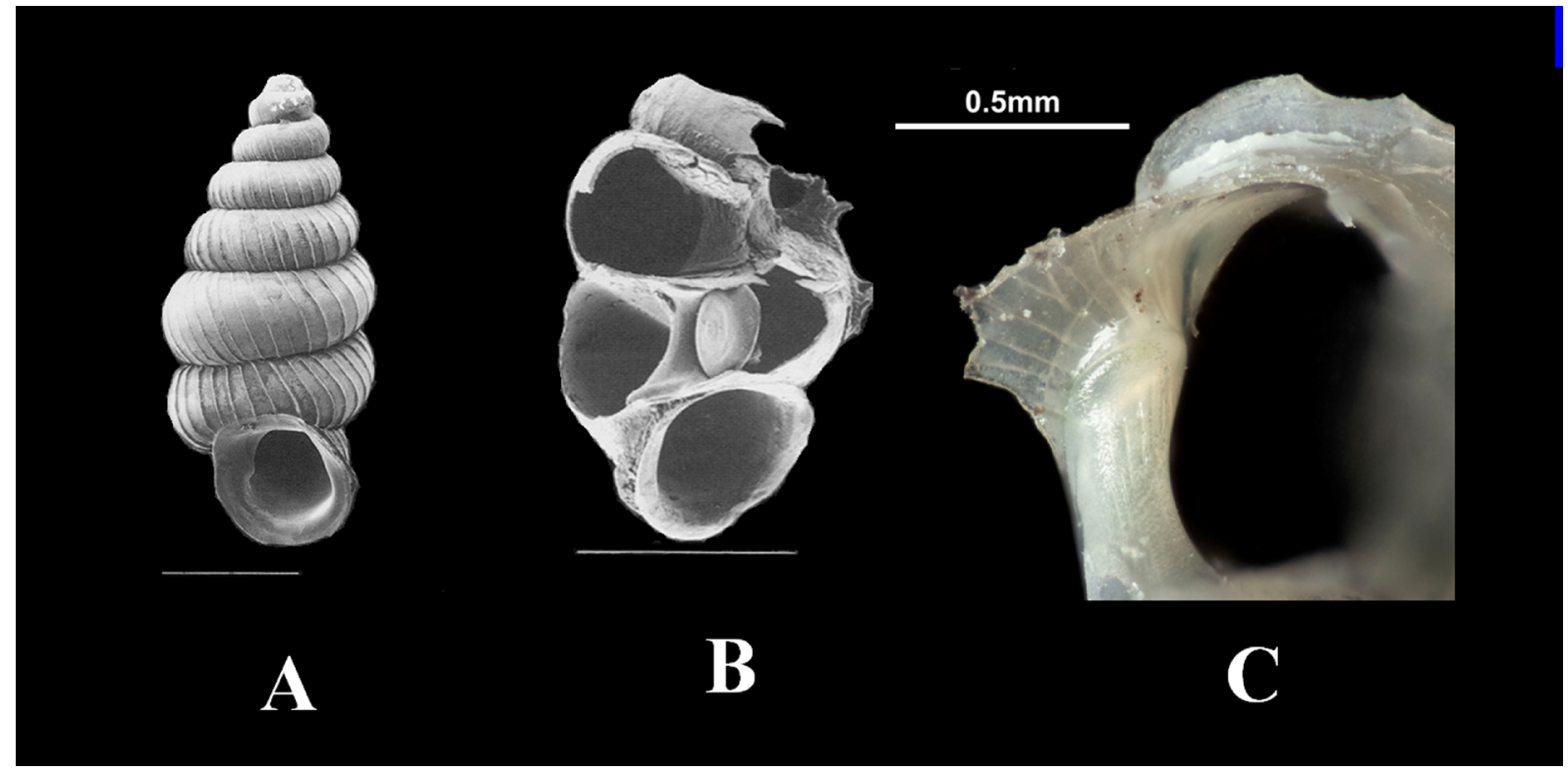

Fig. 10. A. Scanning electron micrograph of Diplommatina folliculus (L. Pfeiffer, 1846) collected by T. Hutton at Simla, India (NHMUK no. 1856.9.15.22), scale bar $1 \mathrm{~mm}$ (Naggs 1997, fig. 10). B. Shell collected by W. Boys at Landour, India, showing the columellaris, the operculum and the inner parietalis (Prt1) (NHMUK no. 1842.7.4.492), scale bar $1 \mathrm{~mm}$ (Naggs 1997: fig. 11). C. T. Hutton's shell from Simla, India (NHMUK no. 1856.9.15.22), showing the columellaris.

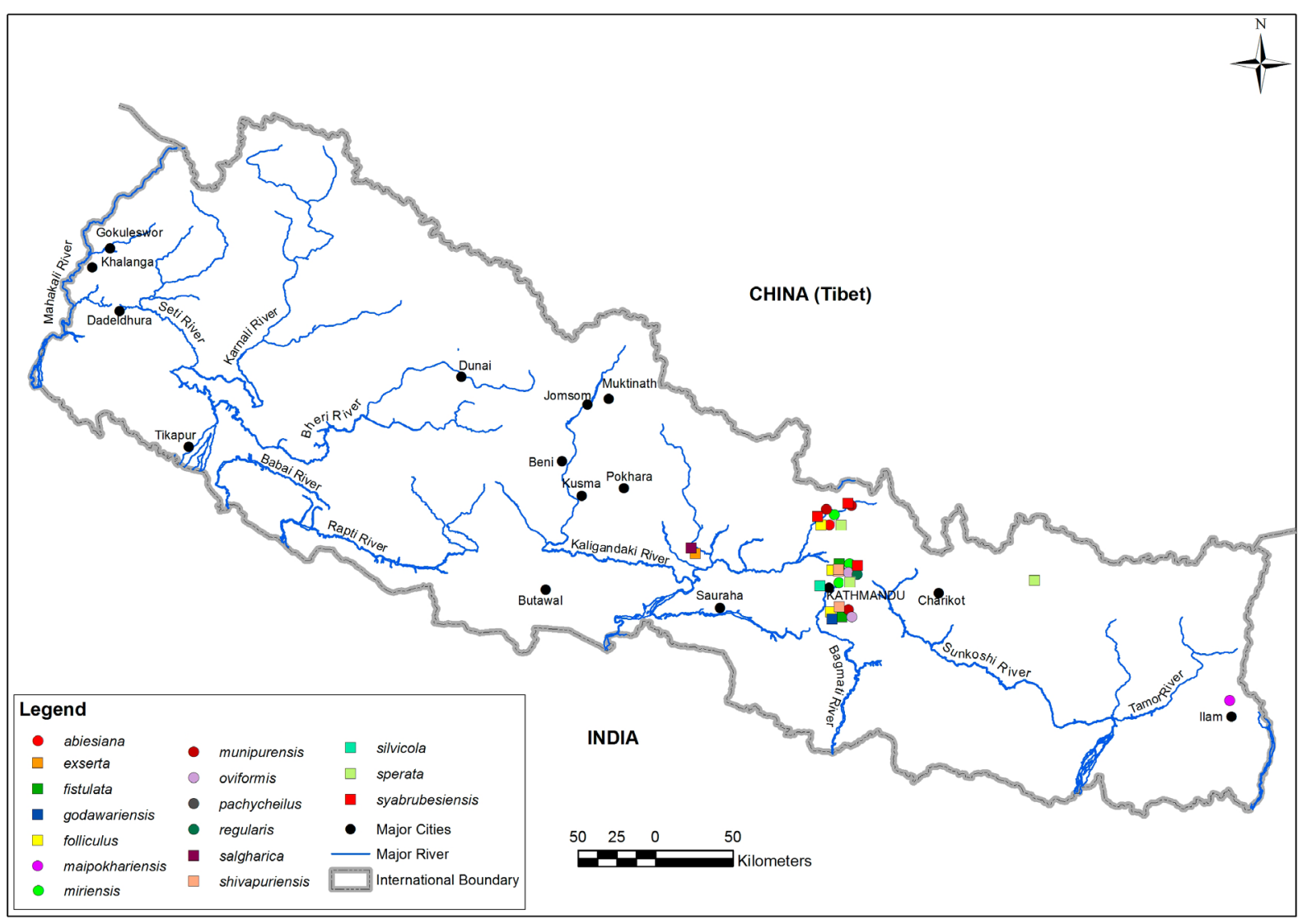

Fig. 11. Distribution of Diplommatina species in Nepal. 
The genus Diplommatina contains highly endemic species. Ramakrishna et al. (2010) listed 66 species from India, 60 (91\%) of which are endemic to India and, of these, $95 \%$ are endemic to the Himalaya. The distribution range of Diplommatina in Nepal (Fig. 11) is restricted to the mountainous areas in Central Nepal, with many species $(\mathrm{n}=11)$ between $2000 \mathrm{~m}$ and $2500 \mathrm{~m}$, while only three species are reported below $1500 \mathrm{~m}$, and no species below $700 \mathrm{~m}$. None of the diplommatinids were collected along the Mahakali River corridor in far West Nepal or the Kaligandaki River corridor in western Central Nepal. This might be due to the low altitudes (below $500 \mathrm{~m}$ ) of these survey sites. Grytness \& Vetaas (2002) reported similar species diversity patterns of plants in Nepal, with maximum plant species richness steeply increasing with altitude between $1500 \mathrm{~m}$ and $2500 \mathrm{~m}$, but decreasing again above $2500 \mathrm{~m}$. Vermeulen (1993) also found a high degree of endemism of Diplommatina species in the mountain areas in Borneo.

\section{Acknowledgements}

P.B. Budha received funding from the RBINS, the Darwin Initiative (NHM) and the Malacological Society of London. We sincerely thank the Department of National Parks and Wildlife Conservation, Babarmahal, Kathmandu, and the wardens of the Langtang National Park and Shivapuri National Park for providing collection permits. P.B. Budha appreciates the field assistance of Ramesh Devkota, Naresh Kohar and Kuber Saud. We also thank Jonathan Ablett (NHM), Rose Sablon (RBINS) and Yves Samyn (RBINS) for providing access to the collections in their institutions. We are grateful to Julien Cillis (RBINS) for the SEM images and to Dammar S. Pujara, Kathmandu for preparing GIS figures (Figs 1 and 12). We are indebted to Edi Gittenberger (Naturalis Biodiversity Center, the Netherlands) and Eike Neubert (Naturhistorisches Museum der Bürgergemeinde Bern, Switzerland) for their valuable input on an earlier draft of the manuscript. The Biodiversity Heritage Library provided support by making old literature freely available (www.biodiversityheritagelibrary.org).

\section{References}

Benson W.H. 1849. Characters of Diplommatina, a new genus of terrestrial mollusks belonging to the family of Carychiadae, and of a second species contained in it; also of a new species of Carychium inhabiting the Western Himalaya. Annals and Magazine of Natural History, Series 2 4: 193-195. https:// doi.org/10.1080/03745486009494813

Benson W.H. 1852. Notice of an Australian Diplommatina; and characters of new East Indian Helicidae from Darjiling and Sincapore. Annals and Magazine of Natural History, Series 2 10: 348-351. https:// doi.org/10.1080/03745485609495711

Benson W.H. 1853a. Additional character of the shell of the cyclostomatous genus Alycaeus of Gray with descriptions of its animal inhabitant, - of a fourth species, - and of other new Indian Cyclostomata, also, remarks on an unrecorded character in Diplommatina. Annals and Magazine of Natural History, Series 2 11: 283-287. https://doi.org/10.1080/037454855609495767

Benson W.H. 1853b. Further observations on the animal of Diplommatina (including a note by Capt. T. Hutton). Annals and Magazine of Natural History, Series 2 11: 433-435. https://doi. org/10.1080/037455485609495805

Benson W.H. 1855. Notice on the question of the presence of an operculum in the genus Diplommatina, Benson, and description of a new species. Annals and Magazine of Natural History, Series 2 15: 329331. https://doi.org/10.1080/037454809495434

Benson W.H. 1857. Characters of Streptaulus, a new genus, and of several species of the Cyclostomacea from Sikkim, the Khasia Hills, Ava, and Pegu. Annals and Magazine of Natural History, Series 2 19: 201-211. https://doi.org/10.1080/00222935708681840 
Blanford W.T. 1862. Contribution to Indian Malacology, No. III. Descriptions of new operculated land shells from Pegu, Arakan and the Khasi Hills. Journal of the Asiatic Society of Bengal 31: 135-145.

Blanford W.T. 1865. Contributions to Indian Malacology, No. V. Descriptions of new land shells from Arakan, Pegu and Ava; with notes on the distribution of described species. Journal of the Asiatic Society of Bengal 34: 66-105.

Blanford W.T. 1867. The genus Plectostoma H. Adams, and on the animal of Diplommatina, Benson. Annals and Magazine of Natural History, Series 3 19: 305-307.

Budha P.B., Naggs F. \& Backeljau T. 2015. Annotated checklist of the terrestrial gastropods of Nepal. ZooKeys 492: 1-48. https://doi.org/10.3897/zookeys.492.9175

Fulton H. 1901. Descriptions of some supposed new species of Diplommatina, Opisthostoma, and a new variety of Alycaeus from N. Borneo, Banguey Island and Darjeeling. Annals and Magazine of Natural History, Series 7 8: 242-245. https://doi.org/10.1080/03745480109442915

Godwin-Austen H.H. 1868. Figures of the species of Diplommatina, Benson, hitherto described as inhabiting the Himalayas, Khasi Hills and Burma, with some additional forms from Darjiling and the Khasi Hills. Journal of the Asiatic Society of Bengal 37: 83-84.

Godwin-Austen H.H. 1886. Land and freshwater Mollusca of India. Conchologia Indica 1 (5): 165-185.

Godwin-Austen H.H. 1892. On new species and varieties of the land molluscan genus Diplommatina from the Garo, Naga and Munipur Hill-ranges, Assam. Proceedings of the Zoological Society of London 35: 509-520.

Godwin-Austen H.H. 1897. Land and freshwater Mollusca of India including South Arabia, Baluchistan, Afghanistan, Kashmir, Nepal, Burma, Pegu, Tenasserim, Malay Peninsula, Ceylon and other Islands of the Indian ocean. Conchologia Indica 2 (7): 1-46.

Godwin-Austen H.H. 1917. Zoological results of the Abor Expedition, Mollusca 6. Records of the Indian Museum 8: 547-559.

Gray J.E. 1850. Nomenclature of Molluscous animals and shells in the collection of the British Museum. Part I. Cyclophoridae. Spottiswoodes and Shaw, London.

Gray J.E. 1853. On the operculum of the genus Diplommatina. Annals and Magazine of Natural History, Series 2 12: 9-10. https://doi.org/10.1080/03745485709496261

Gray J.E. 1855. The operculum of Diplommatina by Capt. Thomas Hutton. Annals and Magazine of Natural History, Series 2 16: 300.

Grytness J.A. \& Vetaas O.R. 2002. Species richness and altitude: a comparison between null models and interpolated plant species richness along the Himalayan altitudinal gradient, Nepal. The American Naturalist 159: 294-304. https://doi.org/10.1086/338542

Gude G.K. 1921. The fauna of British India. Mollusca-III (Land operculates: Cyclophoridae, Truncatellidae, Assimineidae, Helicinidae). Today \& Tomorrow's Printers \& Publishers, New Delhi.

Hanley S. \& Theobald W. 1876. Conchologia Indica; being illustrations of the land and freshwater shells of British India. London. https://doi.org/10.5962/bhl.title.14456

Hwang C.C., Chang K.M. \& Tada A. 2009. Two new species of the land snail genus Diplommatina (Benigoma) Kuroda, 1928 (Gastropoda: Diplommatinidae) from Taiwan. Bulletin of Malacology 33: 21-36.

Kobelt W. 1902. Das Tierreich. Eine Zusammenstellung und Kennzeichnung der rezenten Tierformen. Mollusca: Cyclophoridae, Lief. 16. R. Friedlander und Sohn Verlag, Berlin. 
Kuznetsov A.G. \& Schileyko A.A. 1997. New data on Enidae (Gastropoda, Pulmonata) of Nepal. Ruthenica 7: 133-140.

Liew T.S., Vermeulen J.J., Marzuki M.E \& Schilthuizen M. 2014. A cybertaxonomic revision of the micro-land snail genus Plectostoma Adam (Mollusca, Caenogastropoda, Diplommatinidae), from Peninsular Malaysia, Sumatra and Indochina. ZooKeys 393: 1-107. https://doi.org/10.3897/ zookeys.393.6717

Macdonald J.D. 1869. On the anatomy of Diplommatina and its affinity with Cyclophorus and Pupina in the Cyclophoridae. Annals and Magazine of Natural History, Series 4 4: 77-81. https://doi. org/10.1080/00222936908696005

Naggs F. 1997. William Benson and the early study of land snail in British India and Ceylon. Archives of Natural History 24: 37-88. https://doi.org/10.3366/anh.1997.24.1.37

Neubert E. \& Bouchet P. 2015. The Diplommatinidae of Fiji - a hotspot of Pacific land snail biodiversity (Caenogastropoda, Cyclophoroidea). ZooKeys 487: 1-85. https://doi.org/10.3897/zookeys.487.8463

Nevill G. 1878. Hand list of Mollusca in the Indian Museum, Calcutta. Part I: Gastropoda: Pulmonata and Prosobranchia-Neurobranchia. Printed by order of Trustees, Calcutta. https://doi.org/10.5962/bhl. $\underline{\text { title. } 11957}$

Pfeiffer L. 1846. Symbolae ad Historiam Heliceorum. Fischer Verlag, Kassel, Germany. https://doi. org/10.5962/bhl.title. 11903

Pfeiffer L. 1848. Monographia Heliceorum Viventium. Descriptiones Systematicas et Criticas, Omnium Huius Familiae Generum et Specierum Hodie Cognitarum. Volumen Premium. Brockhaus, Leipzig. https://doi.org/10.5962/bhl.title.10791

Pfeiffer L. 1856. Verzeichniss der bisher bekannt gewordenen gedeckelten Landschnecken von Cuba. Malakozoologische Blätter 3: 118-150.

Pfeiffer L. 1860. Beschreiber und Abbildung, neuer oder kritischer Land- und Süsswasser Mollusken. Novitates Conchologicae 2 (13-14): 139-160. https://doi.org/10.5962/bhl.title.10371

Raheem D.C., Budha P.B., Naggs F. \& Preece R.C. 2010. An illustrated guide to the land snails of Nepal. The Natural History Museum, London.

Raheem D.C., Taylor H., Ablett J., Preece R.C., Aravind N.A. \& Naggs F. 2014. A systematic revision of the land snails of the Western Ghats of India. Tropical Natural History, Supplement 4: 1-294.

Ramakrishna, Mitra S.C. \& Dey A. 2010. Annotated checklist of Indian land molluscs. Records of Zoological Survey of India, Occasional Paper 306: 1-359.

Simone L.R. 2013. Habeas, a new genus of Diplommatinidae from Central Bahia, Brazil (Caenogastropoda) with description of three new species. Journal of Conchology 41: 519-525.

Theobald W. 1876. Catalogue of the land and freshwater shells of British India. Thacker, Spink, Calcutta.

Vermeulen J.J. 1993. Notes on the non-marine mollusks of the island of Borneo 5. The genus Diplommatina (Gastropoda: Prosobranchia: Diplommatinidae). Basteria 57: 3-69.

Yamazaki K., Yamazaki M. \& Ueshima R. 2013. Systematic review of diplommatinid land snails (Caenogastropoda, Diplommatinidae) endemic to the Palau Islands (1) Generic classification and revision of Hungerfordia species with highly developed axial ribs. Zootaxa 3743: 1-71. https://doi. org/10.11646/zootaxa.3743.1.1

Zilch V.A. 1953. Die Typen und Typoide des Natur-Museums Senckenberg, 9: Mollusca, Cyclophoridae, Diplommatininae. Archiv für Molluskenkunde 82: 1-47. 
Manuscript received: 3 April 2016

Manuscript accepted: 28 November 2016

Published on: 21 July 2017

Topic editor: Rudy Jocqué

Section editor: Kurt Jordaens

Desk editor: Chloe Chester

Printed versions of all papers are also deposited in the libraries of the institutes that are members of the EJT consortium: Muséum national d'Histoire naturelle, Paris, France; Botanic Garden Meise, Belgium; Royal Museum for Central Africa, Tervuren, Belgium; Natural History Museum, London, United Kingdom; Royal Belgian Institute of Natural Sciences, Brussels, Belgium; Natural History Museum of Denmark, Copenhagen, Denmark; Naturalis Biodiversity Center, Leiden, the Netherlands; Museo Nacional de Ciencias Naturales-CSIC, Madrid, Spain; Real Jardín Botánico de Madrid CSIC, Spain. 